\title{
Dictyotaceae (Dictyotales, Phaeophyceae) species from French Polynesia: current knowledge and future research
}

\author{
Tohei Theophilus ${ }^{\mathrm{a}}$, Christophe Vieira ${ }^{\mathrm{b}}$, Gérald Culiolic, \\ Olivier P. Thomas ${ }^{d}$, Antoine De Ramon N'Yeurt ${ }^{\mathrm{e}}$, Serge Andréfouët ${ }^{\mathrm{f}}$, \\ Lydiane Mattio $^{g, h}$, Claude E. Payrif and Mayalen Zubia ${ }^{\mathrm{a}, *}$ \\ ${ }^{a}$ University of French Polynesia, UMR-EIO, LabEx CORAIL, BP6570, 98702 Faa'a, Tahiti, French \\ Polynesia \\ ${ }^{\mathrm{b}}$ Phycology Research Group and Centre for Molecular Phylogenetics and Evolution, Ghent University, \\ Krijgslaan 281 (S8), Ghent, Belgium \\ ${ }^{\mathrm{c}}$ Université de Toulon, MAPIEM, Toulon, France \\ ${ }^{\mathrm{d}}$ Marine Biodiscovery, School of Chemistry and Ryan Institute, National University of Ireland Galway, \\ University Road, Galway, Ireland \\ ${ }^{\text {e} P a c i f i c ~ C e n t r e ~ f o r ~ E n v i r o n m e n t ~ a n d ~ S u s t a i n a b l e ~ D e v e l o p m e n t, ~ T h e ~ U n i v e r s i t y ~ o f ~ t h e ~ S o u t h ~ P a c i f i c, ~ S u v a, ~}$ \\ Fiji \\ ${ }^{f}$ French National Research Institute for Sustainable Development, UMR 9220/250 ENTROPIE \\ (IRD-UR-CNRS), Noumea, New Caledonia \\ gblue[c]weed, Locmaria-Plouzané, France \\ ${ }^{\mathrm{h}}$ Department of Biological Sciences, University of Cape Town, Rondebosch, South Africa \\ *Corresponding author: E-mail: mayalen.zubia@upf.pf
}

\section{Contents}

1. Introduction

2. Diversity and distribution of the family Dictyotaceae in French Polynesia

3. Ecological dynamics of Dictyotaceae in Tahiti

3.1 Abundance, seasonality, and habitat of Dictyotaceae in Tahiti

3.2 Main factors controlling the abundance of Dictyotaceae species

3.2.1 Abiotic factors

3.2.2 Biotic factors

3.3 Is there a risk for further macroalgae proliferation in Tahiti?

4. Potential for the development of biotechnological applications

4.1 Chemodiversity \& biological activities

4.2 Applications

4.2.1 Human consumption

4.2.2 Animal nutrition

4.2.3 Health care, medicinal, pharmaceutical, and cosmetic properties 
$\begin{array}{ll}\text { 5. Scope for future research } & 37\end{array}$

$\begin{array}{ll}\text { Acknowledgments } & 37\end{array}$

$\begin{array}{ll}\text { Appendix A Supplementary data } & 38\end{array}$

References $\quad 38$

\section{Abstract}

The coral reefs of French Polynesia (FP) have experienced repeated macroalgal blooms over the last decades. These events have prompted intense efforts in fundamental and applied research on macroalgae in this ecoregion, especially regarding species of the order Fucales (Turbinaria ornata and Sargassum pacificum). Recently, however, these proliferations have occurred with a higher frequency, and they now involve additional species. Specifically, over the past decade, the abundance of species belonging to the Dictyotaceae family (e.g., Dictyota bartayresiana and Spatoglossum asperum) has increased on coral reefs around Tahiti Island, the largest and most inhabited island in FP. On the course of evolution, these species have developed physical and chemical defenses to deter grazers, including the production of a wide array of specialized metabolites. These molecules are of particular interest for their promising biological activities as well as for the new Blue Economy opportunities they can offer to FP. We review the current state of knowledge on the diversity, ecology, and potential uses of Dictyotaceae species present in FP. The first section focuses on the diversity and distribution of the family Dictyotaceae in FP. The second part examines the ecological dynamics of Dictyotaceae species in the coral reef ecosystem and their response to various environmental factors. The third and final part reviews the metabolites known from Dictyotaceae species that are present in FP, their associated biological activities, and potential for the development of biotechnological applications in FP.

\section{Introduction}

French Polynesia (FP) is a vast territory $\left(5.5\right.$ million $\left.\mathrm{km}^{2}\right)$ in the South Pacific Ocean $\left(7^{\circ} \mathrm{S}-28^{\circ} \mathrm{S} ; 134^{\circ} \mathrm{W}-155^{\circ} \mathrm{W}\right)$ consisting of 118 islands (34 high volcanic islands and 84 atolls) that belong to five archipelagos (Austral, Gambier, Marquesas, Society, and Tuamotu; Andréfouët \& Adjeroud, 2019, Fig. 1). It harbors a wide variety of habitats and climates, ranging from high volcanic islands with fringing and barrier reefs in the Society Islands to low-lying coral atolls in the Tuamotus, and from equatorial conditions in the Marquesas to sub-tropical environments in the Austral Islands (Andréfouët \& Adjeroud, 2019).

A remarkable floristic effort has been conducted to record the marine macroalgae in FP, and more than 40 relevant studies have been published since the 19th-century pioneering work made by Bory De Saint-Vincent 

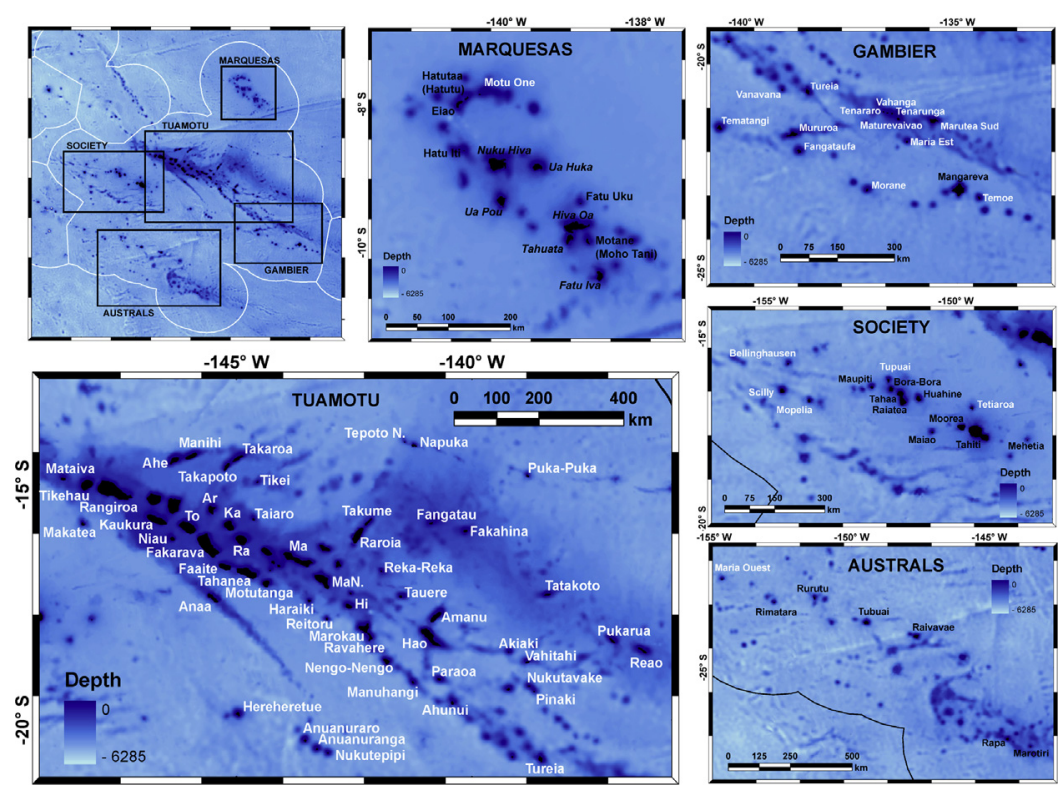

Fig. 1 Map showing the five archipelagos of French Polynesia.

(1828) (Table S1). The most comprehensive contributions were by Setchell (1926), Payri (1982), Payri and Meinesz (1985), Payri and Denizot (1993), Payri and N'Yeurt (1997), and N'Yeurt and Payri (2006; 2007; 2010). Based on previously published records, Payri and N'Yeurt (1997) provided a checklist of 425 taxa including 42 Phaeophyceae, 96 Chlorophyceae, 170 Rhodophyceae, and 117 Cyanophyceae. Using more in-depth analyses and extensive new field collections, N'Yeurt and Payri (2006; 2007; 2009 ; 2010) then revised the total number of marine macroalgal species known from FP to 312, including 32 Phaeophyceae, 82 Chlorophyceae, and 198 Rhodophyceae (Table S1).

The largest macroalgal diversity is recorded for the Society and the Austral Archipelagos, with the latter harboring 20\% of endemic species (N'Yeurt \& Payri, 2006). The remoteness of these islands is likely to explain this high level of endemism (Gillespie, Foody, Rocchini, Giorgi, \& Saatchi, 2008; Kier et al., 2009). In their study, N'Yeurt and Payri (2006) also stressed the role of water temperature and the availability of specific habitats in shaping species distribution across the French Polynesian archipelago. For instance, in the Marquesas Islands, the absence of barrier reefs and lagoons, and the exposure to oceanic swell have been put forward to explain the dominance of crustose coralline algae and the low Phaeophyceae specific richness (Payri, N’Yeurt, Fiat, \& Andréfouët, 2016). Because the Society, Austral, and Gambier archipelagos harbor more substantial habitat diversity 
(e.g., lagoons, fringing, and barrier reefs) compared to the Tuamotus, only consisting of atolls, it is expected that they harbor higher biodiversity (Sanciangco, Carpenter, Etnoyer, \& Moretzsohn, 2013). They also happen to have received most of the sampling effort (Table S1). Since 2003, a series of scientific expeditions and research programs using both morphological and molecular approaches (the Biocode project in Moorea, the Pakaihi $i$ te Moana expedition in the Marquesas, the Global Reef Expedition of the Khaled bin Sultan Living Ocean Foundation in the Gambier Islands, and the AlgalReef project in the Tuamotus) have been carried out to increase sampling efforts and better understand the distribution of macroalgal diversity in FP. The first published studies to use a molecular-based approach for the taxonomic revision of FP macroalgae focused on the Sargassaceae family (Fucales, Phaeophyceae; Rohfritsch, Payri, Stiger, \& Bonhomme, 2007, 2010; Mattio, Payri, \& Stiger-Pouvreau, 2008). Other molecular investigations of FP species appeared sporadically as a component of regional or global studies, for example for the red encrusting algal Order Corallinales (Rhodophyceae; Bittner et al., 2010; Caragnano et al. 2018), the red algal genus Asparagopsis (Bonnemaisoniales, Rhodophyceae; Dijoux, Viard, \& Payri, 2014), the green algal genus Halimeda (Verbruggen, De Clerck, N'Yeurt, Spalding, et al., 2006) or the brown algal genera Dictyota (Dictyotales, Phaeophyceae; De Clerk et al., 2006) and Lobophora (Dictyotales, Phaeophyceae; Vieira, Camacho et al., 2016).

In general, Phaeophyceae is the group that has received the most attention in FP. Indeed, despite being the least diverse lineage compared to Chlorophyceae and Rhodophyceae, Phaeophyceae species often represent the most abundant biomass, are particularly significant ecologically (e.g., Sargassum beds provide food, habitat and nursery grounds for a wide array of marine organisms; Chaves, Pereira, \& Feitosa, 2013), and have also been put forward for their economic potential (Zubia, Payri, Deslandes, \& Guezennec, 2003; Zubia, Payri, \& Deslandes, 2008; Zubia, Andréfouët, \& Payri, 2014). Currently, taking into account the latest molecular work on Lobophora (Vieira, Camacho et al., 2016; 2017), the diversity of Phaeophyceae in FP accounts for 44 species (26 Dictyotales, 8 Ectocarpales, 4 Fucales, 1 Ralphsiales, 1 Scytothamnales, 2 Sphacelariales, 2 Tilopteridales) (Table 1). The highest Phaeophyceae diversity is reported for the Society Archipelago with 22 species. Turbinaria ornata and Sargassum pacificum (Fucales) are the most prevalent species, particularly in the case of abnormal proliferation, during which they represent the main species involved (Stiger \& Payri, 1999a, 1999b; Payri \& Stiger, 2001). Their molecular diversity was assessed in detail (Mattio et al., 2008; Rohfritsch et al., 2007, 2010). In contrast, the more species-rich order Dictyotales has received little or no attention 
Table 1 Phaeophyceae species of French Polynesia and their distribution across the five archipelagos (Mattio et al., 2008; N'Yeurt \& Payri, 2006; 2010; Vieira, Camacho et al., 2016; 2017).

Austral Gambier Marquesas Society Tuamotu

\section{Dictyotales Bory}

Dictyopteris repens

$+$

(Okamura) Børgesen

Dictyota acutiloba $\quad+$

J.Agardh

Dictyota bartayresiana J.V. +

Lamouroux

Dictyota ceylanica Kützing

Dictyota friabilis Setchell

Dictyota hamifera Setchell

Lobophora obscura

(Dickie) C.W.Vieira,

De Clerck \& Payri

Lobophora pacifica (Setch.)

C.W.Vieira, De

Clerck \& Payri

Lobophora sp.6

Lobophora sp.11

Lobophora sp.13

Lobophora sp.17

Lobophora sp.19

Lobophora sp.31

Lobophora sp.32

Lobophora sp. 57

Lobophora sp.70

Lobophora sp.73

Lobophora sp.74

Lobophora variegata

(J.V.Lamouroux)

Womersley ex

E.C.Oliveira

Padina boryana Thivy

Padina melemele ${ }^{\star}$

I.A.Abbott \&

Magruder

Padina pavonica

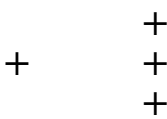

+
+

$+$

$+$

$+\quad+$

$+\quad+$

$+$

$+$

$+$

$+$

$+$

$+$

$+$

$+$

$+$

$+$

$+$

$+$

$+\quad+$

$+\quad+$

$+$

(Linnaeus) Thivy

Padina stipitata Tanaka \& +

Nozawa 
Table 1 Phaeophyceae species of French Polynesia and their distribution across the five archipelagos (Mattio et al., 2008; N'Yeurt \& Payri, 2006; 2010; Vieira, Camacho et al., 2016; 2017).—cont'd

\begin{tabular}{|c|c|c|c|c|c|}
\hline & Austral & Gambier & Marquesas & Society & Tuamotu \\
\hline $\begin{array}{l}\text { Spatoglossum asperum } \\
\text { J.Agardh }\end{array}$ & & + & & + & \\
\hline $\begin{array}{l}\text { Stypopodium } \\
\text { australasicum }{ }^{\star} \\
\text { (Zanardini) Allender } \\
\text { \& Kraft }\end{array}$ & + & & & & \\
\hline
\end{tabular}

\section{Ectocarpales Bessey}

Chnoospora implexa J.Agardh

Chnoospora minima (Hering) Papenfuss

Cladosiphon novaecaledoniae ${ }^{\star}$ Kylin

Colpomenia sinuosa (Mertens ex Roth) Derbès \& Solier

Hincksia mitchelliae (Harvey) P.C.Silva Hydroclathrus clathratus (C.Agardh) M.Howe Hydroclathrus tumulis ${ }^{\star}$ Kraft \& Abbott

Rosenvingea intricata (J.Agardh) Børgesen

$\begin{array}{lllll}+ & + & & + & \\ + & & + & + & \\ + & + & & \\ + & & & \\ & & & & \\ + & & & \\ + & + & & \\ + & & & + \\ + & & & \end{array}$

\section{Fucales Bory}

Sargassum echinocarpum $\quad+\quad+$ J.Agardh

Sargassum obtusifolium + J.Agardh

Sargassum pacificum Bory

Turbinaria ornata

(Turner) J.Agardh

\section{Ralfsiales Nakamura ex P.-E.Lim \& H.Kawai}


Table 1 Phaeophyceae species of French Polynesia and their distribution across the five archipelagos (Mattio et al., 2008; N'Yeurt \& Payri, 2006; 2010; Vieira, Camacho et al., 2016; 2017).-Cont'd

Austral Gambier Marquesas Society Tuamotu

\section{Scytothamnales A.F.Peters \& M.N.Clayton}

Asteronema

breviarticulatum

(J.Agardh) Ouriques

\& Bouzon

\section{Sphacelariales Migula}

Sphacelaria rigidula ++

Kützing

Sphacelaria tribuloides

Meneghini

\section{Tilopteridales Bessey}

Cutleria irregularis $\quad+$

I.A.Abbott \&

Huisman

Cutleria mollis ${ }^{\star}$ Allender $\quad+$

\& Kraft

\begin{tabular}{llllll}
\hline $\begin{array}{c}\text { Number of species } \\
\text { per archipelago }\end{array}$ & 21 & 15 & 8 & 22 & 6 \\
\hline
\end{tabular}

( $)$ record is for Rapa Island only.

although a significant increase in their abundance has been observed on the reefs surrounding the island of Tahiti over the past decade (Zubia, pers. obs.). The present study reports the first detailed assessment of the family Dictyotaceae in FP and, as a background, provides a review of the current state of knowledge on the species diversity, ecology, and potential uses of Dictyotaceae species present in FP.

\section{Diversity and distribution of the family Dictyotaceae in French Polynesia}

The order Dictyotales is composed of only one family, the Dictyotaceae, which is subdivided into 19 genera (Bittner et al., 2008; Guiry \& Guiry, 2019). Most Dictyotaceae belong to three genera, namely Dictyota, Lobophora, and Padina, mainly present in tropical regions (Silberfeld, 

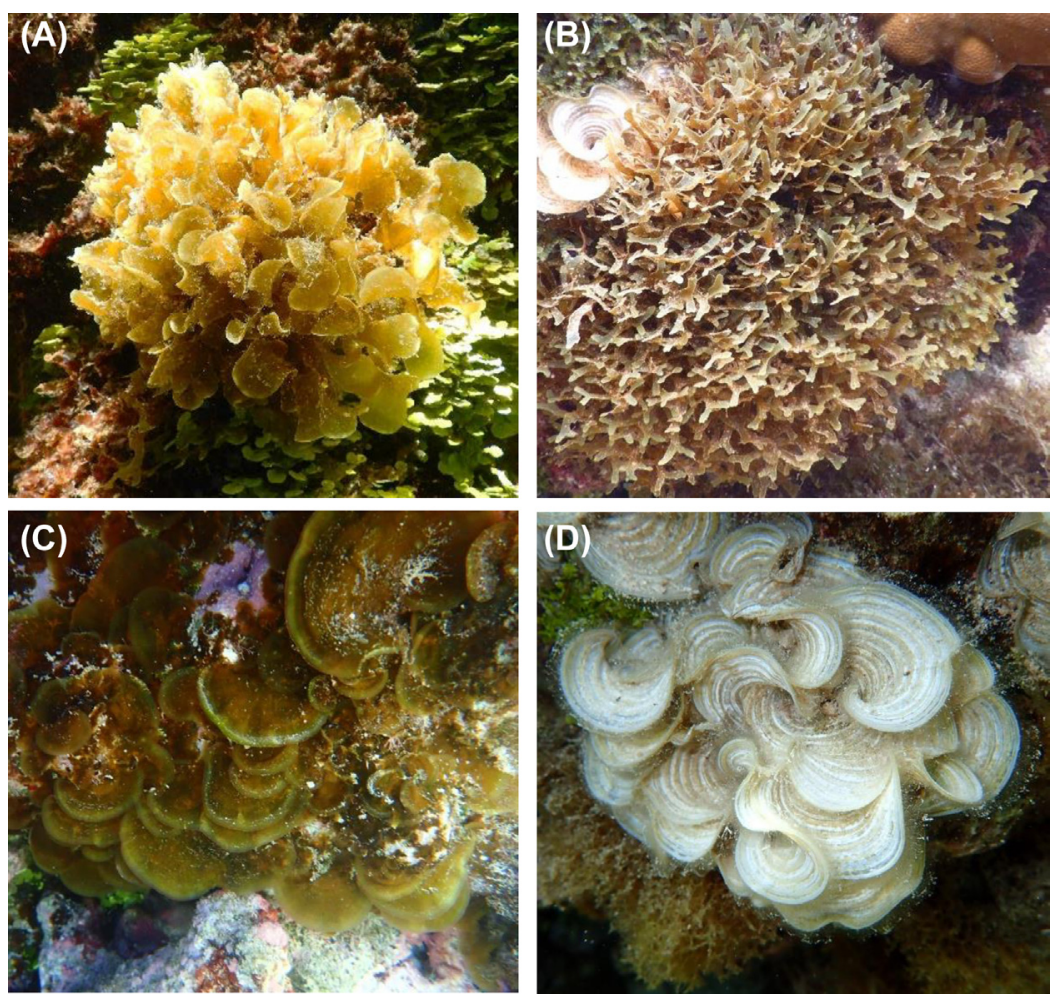

Fig. 2 Illustrations of the most abundant Dictyotaceae species in Tahiti Island: (A) Spatoglossum asperum; (B) Dictyota bartayresiana; (C) Lobophora pacifica; (D) Padina boryana. @: Zubia M., UPF.

Rousseau, \& De Reviers, 2014; Vieira et al., 2017). Based on the available literature, we listed a total of 26 Dictyotaceae species recorded from FP that belong to six genera: Dictyopteris (1 species), Dictyota (5), Lobophora (14), Padina (4), Spatoglossum (1) and Stypopodium (1) (Table 1; Fig. 2). The molecular work carried out on the genus Lobophora by Vieira, Camacho et al. (2016; 2017), at the Indo-Pacific scale, extends the known diversity to more than 14 taxa in FP, including two new species, L. pacifica and L. obscura, and 12 undescribed species (Table 1). Molecular analyses also identified three Dictyota species in FP: D. ceylanica, D. hamifera, and D. friabilis (Tronholm, Steen et al., 2010; Tronholm, Sansón, Afonso-Carillo, Verbruggen, De Clerck, 2010). Except for Lobophora and Dictyota, none of the other Dictyotaceae genera have been re-assessed using molecular data, and the French Polynesian Dictyotaceae diversity is probably largely underestimated. 
Compared to other archipelagos, the Society Islands have been the subject of more detailed studies, and 11 Dictyotaceae species have been recorded (Table 1). Between November 2017 and September 2018, we collected a total of 49 specimens of Dictyotaceae at three sites in Tahiti (Arue, Faa'a, and Punaauia). The methods are detailed in the Supplementary Material S2. The resulting species list is presented in Table 2 and includes, in particular, the new species L. pacifica described by Vieira, Camacho et al. (2016). This species was previously recorded as L. variegata, which, as a result of the revision, is now geographically restricted to the Caribbean region. Our observations confirmed the presence of most of the species listed by N'Yeurt and Payri (2006), except Dictyopteris repens. The molecular analyses carried out on our samples also revealed the presence of species previously unrecorded from Tahiti, as well as previous misidentifications. This is the case of two Padina species that were previously overlooked in FP: P. boergesenii (previously misidentified in FP as P. pavonica, a widely distributed Atlantic and Mediterranean species; Gómez Garreta, Rull, \& Ribera Siguán, 2007) and P. minor (previously subsumed in FP under P. boryana) (Table 2).

\section{Ecological dynamics of Dictyotaceae in Tahiti}

To better understand the ecological dynamics of the Dictyotaceae species around Tahiti Island, we conducted several surveys during a period of one year (March 2018 to March 2019) at two sites, on the north coast (Arue $17.51^{\circ} \mathrm{S}-149.54^{\circ} \mathrm{W}$ ) and on the west coast (Punaauia $\left.17.66^{\circ} \mathrm{S}-149.60^{\circ} \mathrm{W}\right)$. Methods are detailed in the supplementary material S2. This section updates the previous knowledge on the ecology of these species using data obtained during this monitoring (percent cover, water temperature, swell, and nutrients). A bibliographical synthesis of the biotic factors that influence these populations is also presented. Finally, we discuss the risk of Dictyotaceae proliferation in FP.

\subsection{Abundance, seasonality, and habitat of Dictyotaceae in Tahiti}

All species, genera, and sites included, the percent cover of Dictyotales varied from $3.39 \pm 9.68 \%$ in October to $14.55 \pm 5.16 \%$ in March 2018 (Table S2). The maximum abundances were observed on reefs of Punaauia. We provide the results for each genus in Table 3 and discuss them below.

Lobophora. Lobophora species were found in a wide diversity of habitats. Because of limited morphological differences between Lobophora species, 
Table 2 Dictyotaceae species collected at different sites around Tahiti Island during previous studies.

Species

Dictyopteris repens (Okamura)Børgesen

Dictyota bartayresiana J.V.Lamouroux

Dictyota ceylanica Kützing

Dictyota friabilis Setchell

Dictyota hamifera Setchell

Lobophora pacifica (Setch.) C.W.Vieira, De Clerck \& Payri

Padina boryana Thivy

Padina boergesenii Allender \& Kraft

Padina minor Yamada

Spatoglossum asperum J.Agardh

Afaahiti Arue

Faa'a

Paea

Papeari Punaauia

$+$

$\star$

$\star$

$+/ \star / \diamond$

$+/ \diamond$

$+$

$+$

$+$

\section{Tata'a Markers used}

$-$

$\operatorname{cox} 3 / \mathrm{psbA}$

$\operatorname{cox} 3 / \mathrm{psb} / / \operatorname{cox} 1 / 26 \mathrm{~S}$

psbA

$\mathrm{psb} A / \operatorname{cox} 1 / \operatorname{cox} 3 / \mathrm{nad} 1$

$\operatorname{cox} 3 / \mathrm{rbcL}$

$\cos 3$

$\operatorname{cox} 3$

$\operatorname{cox} 3 / \mathrm{psbA}$

psbA

(+): N’Yeurt \& Payri, 2006; (§): Vieira, Camacho et al., 2016, 2017; Tronholm, Sansón, Afonso-Carillo, Verbruggen, De Clerck, 2010; Tronholm, Steen et al., 2010; and $(\star)$ new collections between November 2017 and September 2018; the DNA markers used in each study are indicated. 
Table 3 Percent cover (mean $\pm \mathrm{sd}$ ) of Dictyotaceae species measured during our survey in 2018 at Arue and Punaauia (Tahiti Island).

Arue

\begin{tabular}{|c|c|c|c|c|c|c|}
\hline & & & & \\
\hline & March & July & October & March & July & October \\
\hline Dictyotaceae & $\begin{array}{r}4.48 \pm \\
4.18\end{array}$ & $\begin{array}{r}5.22 \pm \\
10.82\end{array}$ & $\begin{array}{r}3.39 \pm \\
9.68\end{array}$ & $\begin{array}{c}14.55 \pm \\
5.16\end{array}$ & $\begin{array}{r}7.42 \pm \\
8.80\end{array}$ & $\begin{array}{r}6.43 \pm \\
6.53\end{array}$ \\
\hline $\begin{array}{l}\text { Dictyota } \\
\quad \text { bartayresiana }\end{array}$ & $\begin{array}{r}3.84 \pm \\
2.69\end{array}$ & $\begin{array}{r}2.53 \pm \\
2.22\end{array}$ & $\begin{array}{r}1.72 \pm \\
1.45\end{array}$ & $\begin{array}{r}6.63 \pm \\
4.82\end{array}$ & $\begin{array}{r}2.59 \pm \\
2.43\end{array}$ & $\begin{array}{r}1.68 \pm \\
1.46\end{array}$ \\
\hline $\begin{array}{l}\text { Dictyota } \\
\text { hamifera }\end{array}$ & $\begin{array}{r}1.53 \pm \\
1.43\end{array}$ & $\begin{array}{r}1.40 \pm \\
1.89\end{array}$ & $\begin{array}{r}2.04 \pm \\
1.48\end{array}$ & - & - & $\begin{array}{r}1.26 \pm \\
1.53\end{array}$ \\
\hline Dictyota friabilis & $\begin{array}{r}0.62 \pm \\
0.52\end{array}$ & $\begin{array}{r}0.27 \pm \\
0.10\end{array}$ & - & $\begin{array}{r}0.57 \pm \\
0.50\end{array}$ & $\begin{array}{r}0.50 \pm \\
0.38\end{array}$ & $0.34^{\star}$ \\
\hline $\begin{array}{l}\text { Dictyota } \\
\text { ceylanica }\end{array}$ & $\begin{array}{r}0.83 \pm \\
0.54\end{array}$ & - & - & - & - & $0.60 \star$ \\
\hline Lobophora spp. & $\begin{array}{r}2.13 \pm \\
1.91\end{array}$ & $\begin{array}{r}4.20 \pm \\
6.68\end{array}$ & $\begin{array}{r}3.18 \pm \\
3.99\end{array}$ & $\begin{array}{r}0.29 \pm \\
0.22\end{array}$ & $\begin{array}{r}1.71 \pm \\
1.44\end{array}$ & $\begin{array}{r}1.57 \pm \\
1.45\end{array}$ \\
\hline Padina spp. & $\begin{array}{r}2.03 \pm \\
3.36\end{array}$ & $\begin{array}{r}0.63 \pm \\
0.41\end{array}$ & $\begin{array}{r}1.16 \pm \\
1.54\end{array}$ & $\begin{array}{r}11.80 \pm \\
13.36\end{array}$ & $\begin{array}{r}5.15 \pm \\
4.57\end{array}$ & $\begin{array}{r}5.37 \pm \\
7.76\end{array}$ \\
\hline $\begin{array}{l}\text { Spatoglossum } \\
\text { asperum }\end{array}$ & - & - & - & $\begin{array}{r}3.24 \pm \\
2.44\end{array}$ & $\begin{array}{r}4.96 \pm \\
5.01\end{array}$ & $\begin{array}{r}2.63 \pm \\
2.15\end{array}$ \\
\hline
\end{tabular}

(-) Species absent; ( $\left.{ }^{\star}\right)$ Species found only once.

identification in the field is difficult. This was a limiting factor for our monitoring, and we only recorded them as Lobophora spp. At all sites surveyed, Lobophora spp. cover was low and ranged from $0.29 \pm 0.22 \%$ (March) to $4.20 \pm 6.68 \%$ (July) (Table 3). The highest abundances were observed during the austral winter (July) at both sites. While these results tend to suggest that Lobophora species are not abundant on Tahitian reefs, they do not account for the cryptic biomass growing under the canopy of other seaweeds (e.g., Sargassum, Turbinaria), or on the underside of rocks and crevices.

Dictyota. Dictyota species can grow on various substrates and can epiphytize numerous organisms (Beach et al., 2003; Herren, Walters, \& Beach, 2006). During our survey, Dictyota bartayresiana was found growing in dense patches or balls of up to $15 \mathrm{~cm}$ in diameter, on coral rubbles, dead corals, and pavement. Sometimes this species was epiphytic on corals, sponges, and other benthic organisms. The most abundant Dictyota species was D. bartayresiana; although its percent cover was under 10\% (Table 3). Monthly surveys found a similar seasonality at both Arue and Punaauia, with the highest abundance occurring in March $(3.84 \pm 2.69 \%$ and $6.63 \pm 4.82 \%$, respectively) and the lowest abundance in October $(1.72 \pm 1.45 \%$ and 
$1.68 \pm 1.46 \%$, respectively) (Table 3). Dictyota hamifera was growing mainly as an epiphyte on Sargassum pacificum or Turbinaria ornata. This species is easy to recognize and distinguish from other species in the genus thanks to its branchlets bearing hooks. At Punaauia, D. hamifera was rare and only found in October 2018 (Table 3). At Arue, this species was found throughout the year within Sargassum beds on the algal crest, with the highest abundant observed on October $2018(2.04 \pm 1.48 \%)$ (Table 3). The species D. friabilis and $D$. ceylanica were found in low abundances $(<1 \%$ cover) in all habitats and at both sites (Table 3).

Padina. The most common Padina species found in Tahiti was P. boryana. Padina species were found throughout the year at Arue and Punaauia mostly on coral rubbles in sandy habitats or located at the base of dead corals. The abundance of Padina was much larger at Punaauia (5-12\%) in comparison to Arue (1-2\%) (Table 3), probably because more sandy sites were surveyed at Punaauia. The abundance of Padina was the lowest during the austral winter (July; $0.63 \pm 0.41 \%$ at Arue, and $5.15 \pm 4.57 \%$ at Punaauia) and reached its maximum during the austral summer (March; $2.03 \pm 3.36 \%$ at Arue and $11.80 \pm 13.36 \%$ at Punaauia) (Table 3).

Spatoglossum. Spatoglossum asperum was commonly found at the base of massive coral colonies (such as Porites) in the lagoon (0.5-2 $\mathrm{m}$ deep) or forming large beds at depths of 15-20 m on the outer slope of Taharaa and Punaauia. This species was also found in large patches at $100 \mathrm{~m}$ deep outside of Papeete harbor (Payri, com.pers.). In lagoons, older plants can reach large sizes $(50 \mathrm{~cm})$ and are heavily epiphytized by crustose coralline algae and turf. During our survey, S. asperum was only found on the reef of Punaauia, where its abundance increased from the beginning of the year to reach a maximum in July $(4.96 \pm 5.01 \%)$, and then declined to reach a minimum abundance in October $(2.63 \pm 2.15 \%)$ (Table 3$)$.

\subsection{Main factors controlling the abundance of Dictyotaceae species}

The combination of bottom-up (e.g., nutrient supply, light availability) and top-down control (e.g., herbivory) usually maintains macroalgal abundance and prevents macroalgal proliferation (Lapointe, Littler, \& Littler, 1997; Littler, Littler, \& Brooks, 2006; Smith, Hunter, \& Smith, 2010). The loss of this ecosystem balance can lead to a proliferation of macroalgae, and in the long-term to ecological phase-shifts (Fong, Frazier, Tompkins-Cook, Muthukrishnan, \& Fong, 2016; Hughes, 1994; Hughes, Graham, Jackson, 
Mumby, \& Steneck, 2010; Rasher, Hoey, \& Hay, 2013). Dictyotales species including members of the genera Lobophora, Dictyota, and Stypopodium have been reported to proliferate in several regions of the world (Barott et al., 2011; Bonaldo \& Hay, 2014; Hughes et al., 2010; Longo \& Hay, 2015; 2017; Rasher et al., 2013). Following reef degradation, damaged corals are initially overgrown by small ephemeral algae, which are quickly replaced by longer-lived taxa, notably Sargassum, Lobophora, Dictyota and Padina, some of which could represent a threat to coral reefs (Brown et al., 2018; Fong \& Paul, 2011, pp. 241-272; Ho \& Carpenter, 2017; Mumby, Steneck, Adjeroud, \& Arnold, 2016; Paul et al., 2011). In the following paragraphs, we discuss some of the main ecological processes known to control the abundance and distribution of Dictyotaceae species globally.

\subsubsection{Abiotic factors}

\subsubsection{Nutrients}

Macroalgae need macronutrients (e.g., carbon, nitrogen, and phosphorus), micronutrients (e.g., iron, zinc, etc.), and vitamins (e.g., vitamin B12) to grow (Lobban \& Harrison, 1994, p. 366). An excess of nutrients can favor the overgrowth of certain species of macroalgae (Zubia, Depetris, Flores, Turquet, \& Cuet, 2018). As a bottom-up factor, nutrification can lead to coral reef degradation (Fabricius, 2005; Lapointe, 1997). Several sources of nutrients have been described including groundwater flow, terrestrial runoff (Camoin, Gautret, Montagioni, \& Cabioch, 1999), upwelling (Camoin et al., 2006), and dissolved organic matter (DOM) derived from reef organisms (Heindel et al., 2012). In Tahiti, during our surveys, nitrogen concentration reached a maximum during the hot and rainy season (November to March; $>1 \mu \mathrm{mol} . \mathrm{L}^{-1}$ ) and a minimum during the cold and dry season (April to October; $<1 \mu$ mol. $\mathrm{L}^{-1}$, Fig. S2). In Tahiti, annual precipitations can reach up to $10,000 \mathrm{~mm} /$ year (Pheulpin, Recking, Sichoix, \& Barriot, 2016). Therefore, the riverine input is particularly significant during the rainy season (November to March), during which large amounts of sediments are released into the lagoon, increasing nutrient concentrations (Pheulpin, Sichoix, Barriot, \& Recking, 2014). In our study, the abundance of $D$. bartayresiana appeared to follow nitrogen concentrations, with the highest percent cover occurring during the rainy/hot season (Table 3; Fig. S2). In Moorea, Clausing and Fong (2016) also reported a higher growth rate in $D$. bartayresiana after a rainy period followed by high light intensity. These observations tend to support the hypothesis that nutrient 
inputs enhance the growth of $D$. bartayresiana. Besides, experiments in the Caribbean reefs have demonstrated that the growth and proliferation of Dictyota spp. were influenced mainly by nutrient enrichment and herbivore exclusion (Sotka \& Hay, 2009).

\subsubsection{Water temperature}

Water temperature has a direct effect on metabolic and photosynthetic rates, which control growth, reproduction, and decay of seaweeds (Lüning \& Tom Dieck, 1989). It is considered a key driver of seasonal fluctuations of algal biomass (Fulton et al., 2014). During our survey, the minimum sea surface temperature (SST) was recorded at Arue in September $2018\left(26.4^{\circ} \mathrm{C}\right)$ and the highest in May 2019 (31.9 ${ }^{\circ} \mathrm{C}$ ) (Fig. S3). The cover of Dictyota bartayresiana and Spatoglossum asperum seemed to follow STT fluctuations in different ways over the survey period (Table 3). During the warm season (November to April), S. asperum was less abundant, and thalli started to deteriorate, while this was the period when $D$. bartayresiana was the most abundant. These observations illustrate the different thermal preferences of $S$. asperum and D. bartayresiana, and, therefore, their distinct seasonality.

\subsubsection{Swell}

Swell is a determinant factor which regulates algal abundance in coral reefs by ripping macroalgae off the reef and exporting them to other coral reefs (Herren et al., 2006). For example, strong swells can rip off macroalgae and contribute to the formation of drifting rafts (Goldberg \& Kendrick, 2004; Zubia et al., 2014). The eastern and northern coasts of Tahiti are exposed to swell mostly during the hot season (October to April), while south swell is almost constant throughout the year (Laurent, Maamaatuaiahutapu, Maiau, \& Varney, 2004). Swells generated by hurricanes and lows, between December and April, may also come from the west (Andréfouët \& Adjeroud, 2019). Data collected during our surveys follow these general patterns (Fig. S3). The swell energy at Punaauia was high during the cold season (May to October), especially in June, September, and October $\left(>30 \mathrm{~kW} \cdot \mathrm{m}^{-1}\right)$, which also coincided with lower abundances of D. bartayresiana $(1.68 \pm 1.46 \%)$ (Table 3; Fig. S3). Spatoglossum asperum was more abundant in July $(4.96 \pm 5.01 \%)$ when the swell energy was the highest at Punaauia (Table 3; Fig. S3). Spatoglossum asperum appeared less influenced by the swell, probably because it occurs far from the reef crest and is protected by massive coral colonies at the base of which it grows. 


\subsubsection{Biotic factors}

\subsubsection{Herbivory}

Herbivory is one of the critical factors that control macroalgal abundance. The lack of grazing due to overfishing, for example, can favor the proliferation of macroalgal species, sometimes leading to phase-shifts where macroalgae-dominated reefs replace coral-dominated reefs (Done, 1992). Macroalgae are also known to naturally produce allelopathic compounds that deter herbivores (Hay, 1997; Rasher \& Hay, 2014; Sotka, Bell, Lowry, $\&$ Poore, 2017). Some herbivores have adapted to tolerate these defenses, but intense grazing pressure can favor macroalgae with a wide range of chemical defenses (Sotka, Bell, Lowry, \& Poore, 2017).

Herbivore assemblages in Moorea, an island of the Society Archipelago near Tahiti, are mainly composed of species that belong to the families Acanthuridae, Scaridae, and Pomacanthidae with six fish species responsible for over $80 \%$ of the total macroalgae biomass consumption: Ctenochaetus striatus, Scarus psittacus, Chlorurus spilurus, Acanthurus nigrofuscus, Zebrasoma scopas, and Naso lituratus (Holbrook, Schmitt, Adam, \& Brooks, 2016). According to Holbrook et al. (2016), sea urchins and other invertebrates contribute little to macroalgal herbivory in Moorea, although Zizka (2012) showed that Dictyota bartayresiana is the most consumed species by the sea urchins Echinometra. Fong (2015) and Fong et al. (2016) reported that grazing is an effective biomass regulator for Dictyota bartayresiana in Moorea, especially by large grazers when there is little influence of nutrients. Dictyota bartayresiana was also rapidly consumed by herbivorous fish species in Fiji (up to $86-100 \%$ after 48 h; Rasher et al., 2013). The efficiency of Dictyota chemical defenses varies depending on herbivorous species (Sotka, Bell, Lowry, \& Poore, 2017). For example, Dictyota pfafii showed significant activity against generalist herbivorous fishes and the sea urchin Lytechinus variegatus, while no effect was observed against the crab Pachygrapsus transversus (Barbosa et al., 2004). Pereira, Cavalcanti, \& Texeira, 2000; Sotka, Bell, Lowry, \& Poore (2017) report that herbivores highly appreciate Dictyota species despite their high level of secondary metabolites.

Grazing is a critical top-down process to maintain low Lobophora cover as illustrated by the shift in assemblages that occurred following herbivore dieoffs in the Caribbean (Van Steveninck \& Breeman, 1987) and the Canary Islands (Sangil, Sansón, Clemente, Afonso-Carrillo, \& Hernández, 2014). In Palau, Mumby et al. (2016) showed that the primary grazers of Lobophora were Acanthuridae. Vieira, Stenger, Moleana, De Clerck, and Payri (2019) demonstrated limited variation in grazing sensitivity in Lobophora species by 
the sea-urchin Diadema setosum and the rabbitfish Siganus lineatus. These authors concluded that spatial and associational refuges are primary defense strategies against herbivores. For instance, in Tahiti, Lobophora spp. are commonly found growing under the canopy of Sargassum and Turbinaria or encrusting reef crevices.

Padina species are calcifying macroalgae that consistently rank low in herbivorous fish preference (Hay, 1991). They are chemically defended by secondary metabolites (Renaud, Hay, \& Schmitt, 1990). For instance, unlike parrotfish species, Siganidae species actively avoid calcified macroalgae such as Padina due to the high acidity of their stomachs, (Mantyka \& Bellwood, 2007; Schupp \& Paul, 1994). Herbivory also plays an essential role in controlling the morphology of some Padina species. For instance, Padina sanctae-crucis and $P$. boergesenii can shift from a vegetative turf morphology (Vaughaniella stage) to a foliose and fan-shaped morphology when grazing pressure is low, allowing them to persist in habitats subject to various grazing pressures (Diaz-Pulido, Villamil, \& Almanza, 2007; Lewis, Norris, \& Searles, 1987). No data is currently available on the effect of grazing on Padina and Spatoglossum species in FP.

\subsubsection{Interactions with corals}

While little is known about the coral reef health in Tahiti due to the absence of surveys, in the neighboring island of Moorea, located $25 \mathrm{~km}$ from Tahiti, the situation is better informed. Since 1979, severe degradations of the coral reefs of Moorea have been observed, and several human and natural disturbances have been incriminated. These include organic and chemical pollution, terrestrial runoff, dredging, coral exploitation, microbial diseases, coral bleaching, and Acanthaster planci infestations (Faure, 1989; Gleason \& Wellington, 1993; Kayal et al., 2012; Trapon, Pratchett, \& Penin, 2011). These disturbances are not only affecting coral species abundance and assemblages (i.e., the decline in Acropora and increasing prevalence of Pocillopora and Porites; Trapon et al., 2011), but they also impact macroalgal assemblages and cover (e.g., Turbinaria ornata; Bittick, Clausing, Fong, Scoma, \& Fong, 2019). As corals decline and macroalgae proliferate, their interactions intensify and potentially affect the survival, growth, reproduction, and recruitment of coral larvae (e.g., Diaz-Pulido, Harii, McCook, \& HoeghGuldberg, 2010; Ritson-Williams, Arnold, Fogarty, Steneck, et al., 2009). Macroalgae then directly or indirectly impact coral health through shading, abrasion, transmitting coral diseases or microbes, and allelochemicals (Hughes et al., 2007; McCook, Jompa, \& Diaz-Pulido, 2001; Nugues, 
Smith, Van Hooindonk, Seabra, \& Bak, 2004; Vieira, Engelen et al., 2016). However, macroalgae-coral interactions are known to be species-specific, which means that different coral species will not be equally sensitive and affected by the same macroalgal species. The genus Lobophora is known for its ability to outcompete corals through direct contact and associated microbiome carrying coral pathogens leading to coral bleaching and death (Vieira, Payri, \& De Clerck, 2015; Vieira, Camacho et al., 2016; Vieira, Engelen et al., 2016). The situation is similar for the genus Dictyota which can induce coral bleaching and death through abrasion and the effect of their associated microbiomes (Barott et al., 2011; Rasher \& Hay, 2010, 2011), and inhibit larval settlement (Diaz-Pulido et al., 2010; Paul et al., 2011). For instance, in Moorea, Longo and Hay (2017) showed that D. bartayresiana lipid-soluble extract could decrease the photochemical efficiency of Pocillopora verrucosa by $20-30 \%$. Similarly, Padina species have been shown to impact the settlement and metamorphosis of Pocillopora damicornis larvae in the Philippines (Maypa \& Raymundo, 2004), and Kaullysing et al. (2016) suggested that Padina boryana overgrowth is potentially stressful to the Acropora muricata colonies. To the best of our knowledge, there is no study reporting negative or positive interactions between Spatoglossum and corals.

\subsection{Is there a risk for further macroalgae proliferation in Tahiti?}

The coral reefs of FP have experienced repeated macroalgal blooms over the last decades. These events mainly involved two species of Sargassaceae (Fucales): Sargassum pacificum and Turbinaria ornata, which also happen to be the most prevalent species in terms of biomass in normal conditions (Payri \& Stiger, 2001; Stiger \& Payri, 1999a, 1999b). These proliferation events have prompted intense efforts in fundamental and applied research on macroalgae in the region. Recently, however, these proliferations have occurred with a higher frequency, and they now seem to involve additional species of the family Dictyotaceae. Indeed, over the past decade, two species of the family Dictyotaceae (Dictyota bartayresiana and Spatoglossum asperum) have become increasingly abundant in the lagoons of Tahiti (Zubia, pers. obs.). However, the percent cover measured during our survey is low at both sites $(<10 \%)$ and does not currently support the hypothesis of an ongoing proliferation of these species. In the absence of previous baseline data, it is not possible to tell whether the abundance of these species has indeed significantly increased over the past decade. In the neighboring island of Moorea, Adam et al. (2011) and Holbrook et al. (2016) have demonstrated that 
intense grazing could prevent the establishment and proliferation of macroalgae. Although this biotic factor was not assessed during our surveys, we recommend that it is included in further studies and monitoring in Tahiti, where inhabitants and environmental pressures are high in comparison to other islands in FP (Andréfouët \& Adjeroud, 2019). With increasing global ocean acidification, this is particularly worrying because naturally acidified reefs tend to host Dictyotaceae species such as Dictyota (Del Monaco, Hay, Gartrell, Mumby, et al., 2017), Lobophora (Bouraké, New Caledonia; Payri, com. Pers.), and Spatoglossum species (Enochs et al., 2015). For instance, Enochs et al. (2015) observed a clear shift from coral to fleshy macroalgae ecosystems at low $\mathrm{pH}$ with Spatoglossum stipitatum covering more than $50 \%$ of the substrate.

\section{Potential for the development of biotechnological applications}

Through evolution, macroalgae have adapted to external pressures (e.g., desiccation, UV radiations, infections, grazing) and to mitigate these pressures some species are producing a wide array of bioactive metabolites (Bischof et al., 2006; Duffy \& Harvilicz, 2001; Steinberg \& De Nys, 2002). With more than 1500 metabolites described, the class Phaeophyceae (brown algae) represents a rich source of natural products that belong to several chemical families such as terpenoids, phenols, fatty acids derivatives, and polysaccharides among others. Within the brown algae, the families Dictyotaceae and Sargassaceae, in particular, are recognized for the production of phenolics (mainly phlorotannins) and terpenoids (mainly sesquiterpenes, diterpenes and meroterpenes) (Carroll, Copp, Davis, Keysers, \& Prinsep, 2019; and previous reports in the series) which are widely used in the industry. Here, we review the metabolites known for the species of Dictyotaceae recorded in FP.

\subsection{Chemodiversity \& biological activities}

Dictyotaceae species are well-known for their outstanding richness in terpenoids (De Paula, Vallim, \& Teixeira, 2011; Vieira et al., 2017), which represents more than $33 \%$ of all the specialized metabolites described from the class Phaeophyceae (Carroll et al., 2019; and previous reports in the series). More specifically, several Dictyotaceae species can biosynthesize a wide array of sesquiterpenes (e.g., Dictyopteris and Taonia spp.), cyclic diterpenes (e.g., Dictyota and Spatoglossum spp.) or meroterpenes, also called terpenoids of 
mixed biogenesis (e.g., Dictyopteris and Stypopodium spp.). Over 200 diterpenes have been isolated from 35 species of Dictyotaceae worldwide, mainly from the genus Dictyota (Chen et al., 2018; Vallim, De Paula, Pereira, \& Teixeira, 2005). Besides their use in taxonomic determination and biogeographic markers, these molecules have been found to exhibit interesting biological activities. Table 4 provides an overview of the compounds and biological activities recorded in the literature for Dictyotaceae species recorded in Tahiti.

Dictyopteris. Aside from two studies on the content of sulfuric acid and inorganic ions of Dictyotaceae species (Sasaki, Kataoka, Kamiya, \& Kawai, 1999; Sasaki, Kataoka, Murakami, \& Kawai, 2004) and on the antineoplastic activity of algae where its extracts were found to be inactive (Kashiwagi, Mynderse, Moore, \& Norton, 1980), no comprehensive work has been published on the chemical characterization of the species Dictyopteris repens. This lack of information is unexpected as Dictyopteris spp. are known to biosynthesize a broad array of specific compounds such as $\mathrm{C}_{11}$ hydrocarbons, sesquiterpenes, merosesquiterpenes or sulfur containing derivatives (Philippus et al., 2018; Zatelli, Philippus, \& Falkenberg, 2018).

Dictyota. Species of the genus Dictyota are mostly known for their ability to produce a wide range of cyclic diterpenes (Chen et al., 2018; Hay, 1997; Kelecom \& Teixeira, 1986; Teixeira \& Kelecom, 1988; Vallim et al., 2005). Cyclic diterpenes found in Dictyotaceae can be divided into three structural groups (Fig. 3). Group I includes compounds obtained through a first C-1/ C-10 cyclization from geranylgeranylpyrophosphate (GGPP) including the prenylated guaiane subgroup among others. Group II contains diterpenes formed from GGPP through a first $\mathrm{C}-1 / \mathrm{C}-11$ cyclization, belonging mainly to the dolabellane subgroup among others. Finally, group III contains compounds derived from a first C-2/C-10 cyclization of the GGPP precursor belonging to the crenulane, xeniane, and dichotomane families subgroups among others (Chen et al., 2018). Among the Dictyota species found in FP, Dictyota bartayresiana appeared as the most studied with several diterpenes isolated (Table 4, Fig. 4). Dictyota bartayresiana was also investigated for its fatty acids (Gosch, Paul, De Nys, \& Magnusson, 2015) and lipid hydroperoxydes contents (Kumari, Singh, Bijo, Reddy, \& Jha, 2012), and it was found to be rich in cellulose which could be interesting for further economic applications (Siddhanta et al., 2009). Several extracts of these species have been assayed for their antibacterial activity (Antonysamy, Velayutham, Mani, Thangaiah, \& Irullappan, 2015; Parmar et al., 2016) and their antiviral properties against Vaccinia virus (Kamat et al., 1992). In 
Table 4 Overview of the biological activities recorded in the literature for Dictyotaceae species present in French Polynesia with indications of the type of molecules reported and the type of extraction used.

Taxa

Dictyotaceae

Dictyotaceae

Diterpenes

Dictyopteris

Dictyopteris

Dictyopteris repens

Dictyopteris repens

$-$

Dictyopteris repens

\section{Dictyota bartayresiana}

Dictyota bartayresiana
Crude extract distilled water

Sulfuric acid and inorganic ions content

Sulfuric acid and

Crude extract inorganic ions content distilled water Ethanol extract known dolabellanes Molecules reported

Extraction methods

Biological activities

$-$

Dictyols (diterpenes)

\section{C11-hydrocarbons,} sulfur compounds, terpenes,

meroditerpenes,

halogenated

compounds and sterols

No compound could be identified in the extracts use in chemotaxonomy

Therapeutic and ecological activities
Herbivory deterrent \&

DCM:MeOH (2:1) -
No Antineoplastic activity

$-$

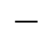

Antiviral (Vaccinia virus)
Palau, Western Caroline Island

Ishigaki Island, Okinawa

Ishigaki Island, Okinawa

Gujarat, India
Location

Worldwide

Worldwide

Worldwide

São Paulo, Brazil

Philippus et al., 2018

\section{References}

Hay, 1997

Kelecom \& Teixeira, 1986

Zatelli et al., 2018

Mannar, India

\section{Kashiwagi et al.,} 1980

Sasaki et al., 1999

Sasaki et al., 2004

Kamat et al., 1992

Bheemasankara Rao et al., 1994 and five new diterpenes 


\begin{tabular}{|c|c|c|c|c|c|}
\hline $\begin{array}{l}\text { Dictyota } \\
\quad \text { bartayresiana }\end{array}$ & - & $\begin{array}{l}\text { Acetone, ethanol and } \\
\text { water extracts }\end{array}$ & Ichtyotoxic activity & Mexico & $\begin{array}{l}\text { De Lara-Isassi et al., } \\
2000\end{array}$ \\
\hline $\begin{array}{l}\text { Dictyota } \\
\quad \text { bartayresiana }\end{array}$ & $\begin{array}{l}\text { A known dolastane, five } \\
\text { known dolabellane, } \\
\text { five new compounds } \\
\text { (3 dolabellanes, } 2 \\
\text { dolastanes) }\end{array}$ & - & - & Mannar, India & $\begin{array}{l}\text { Sarma, Krishna, \& } \\
\text { Kawai, } 2006\end{array}$ \\
\hline $\begin{array}{l}\text { Dictyota } \\
\quad \text { bartayresiana }\end{array}$ & Cellulose rich & Methanol extract & - & India & Siddhanta et al., 2009 \\
\hline $\begin{array}{l}\text { Dictyota } \\
\quad \text { bartayresiana }\end{array}$ & - & Methanol extract & Antioxidant activities & India & $\begin{array}{l}\text { Palanisamy et al., } \\
2010\end{array}$ \\
\hline $\begin{array}{l}\text { Dictyota } \\
\quad \text { bartayresiana }\end{array}$ & Terpenes & Methanol extract & Coral bleaching & Viti Levu, Fiji & $\begin{array}{l}\text { Rasher, Stout, Engel, } \\
\text { Kubanek, \& Hay, } \\
2011\end{array}$ \\
\hline $\begin{array}{l}\text { Dictyota } \\
\quad \text { bartayresiana }\end{array}$ & $\begin{array}{l}\text { Fatty acids and lipid } \\
\text { hydroperoxydes } \\
\text { contents }\end{array}$ & $\begin{array}{l}\text { Chloroform:MeOH } \\
\qquad(1: 2)\end{array}$ & - & $\begin{array}{l}\text { Saurashtra coast, } \\
\text { Gujarat, India }\end{array}$ & Kumari et al., 2012 \\
\hline $\begin{array}{l}\text { Dictyota } \\
\quad \text { bartayresiana }\end{array}$ & $\begin{array}{l}\text { Synthesize silver } \\
\text { nanoparticules } \\
\text { (Ag-NPs) }\end{array}$ & Methanol extract & Antifungal activity & Tamilnadu, India & $\begin{array}{l}\text { Kumar \& Sudha, } \\
\qquad 2013\end{array}$ \\
\hline $\begin{array}{l}\text { Dictyota } \\
\quad \text { bartayresiana }\end{array}$ & - & Methanol extract & $\begin{array}{l}\text { Highest antidiatom and } \\
\text { antifouling }\end{array}$ & Mannar, India & Deepa et al., 2014 \\
\hline $\begin{array}{l}\text { Dictyota } \\
\quad \text { bartayresiana }\end{array}$ & - & Methanol extract & $\begin{array}{l}\text { No haemogglutinin } \\
\text { activity (blood cell } \\
\text { agglutination) }\end{array}$ & Manoli island & $\begin{array}{l}\text { Mangaiyarkarasi, } \\
\text { Kanna, Girija, \& } \\
\text { Gnanamurthy, } \\
2014\end{array}$ \\
\hline
\end{tabular}


Table 4 Overview of the biological activities recorded in the literature for Dictyotaceae species present in French Polynesia with indications of the type of molecules reported and the type of extraction used.-cont'd

\begin{tabular}{|c|c|c|c|c|c|}
\hline Taxa & Molecules reported & Extraction methods & Biological activities & Location & References \\
\hline $\begin{array}{l}\text { Dictyota } \\
\quad \text { bartayresiana }\end{array}$ & - & Methanol extract & $\begin{array}{l}\text { In vivo lethality test } \\
\text { Artemia salina (shrimp) }\end{array}$ & Tamilnadu, India & $\begin{array}{l}\text { Antonysamy, } \\
\text { Thangiah et al., } \\
2015\end{array}$ \\
\hline $\begin{array}{l}\text { Dictyota } \\
\quad \text { bartayresiana }\end{array}$ & - & Methanol extract & $\begin{array}{l}\text { Larvicidal effect on } \\
\text { Culex quinquefasciatus }\end{array}$ & Tamilnadu, India & $\begin{array}{l}\text { Antonysamy et al., } \\
\text { 2015a }\end{array}$ \\
\hline $\begin{array}{l}\text { Dictyota } \\
\quad \text { bartayresiana }\end{array}$ & - & Methanol extract & Antibacterial screening & Tamilnadu, India & $\begin{array}{l}\text { Antonysamy, } \\
\text { Velayutham et al., } \\
2015\end{array}$ \\
\hline $\begin{array}{l}\text { Dictyota } \\
\quad \text { bartayresiana }\end{array}$ & - & Aqueous extract & $\begin{array}{l}\text { Cytotoxicity and } \\
\text { anticancer potential }\end{array}$ & Tamilnadu, India & $\begin{array}{l}\text { Antonysamy, } \\
\text { Thangiah et al., } \\
2015\end{array}$ \\
\hline $\begin{array}{l}\text { Dictyota } \\
\quad \text { bartayresiana }\end{array}$ & - & Crude extract & $\begin{array}{l}\text { Antibacterial } \\
\text { (Staphylococcus aureus } \\
\text { and Escherichia coli) and } \\
\text { antifungal (Candida } \\
\text { albicans) activity }\end{array}$ & Mtwapa, Kenya & Kaaria et al., 2015 \\
\hline $\begin{array}{l}\text { Dictyota } \\
\quad \text { bartayresiana }\end{array}$ & - & Ethanol extract & low antibacterial & Gujarat, India & Parmar et al., 2016 \\
\hline $\begin{array}{l}\text { Dictyota } \\
\text { bartayresiana }\end{array}$ & Lipid soluble extracts & Methanol extract & $\begin{array}{l}\text { Coral bleaching of Porites } \\
\text { spp. }\end{array}$ & $\begin{array}{l}\text { Votua Reef, Viti } \\
\text { Levu, Fij }\end{array}$ & Rasher \& Hay, 2010 \\
\hline Dictyota bartayresii & Diterpenoids & Crude extract & Antifungal activity & Belize & $\begin{array}{l}\text { Norris \& Fenical, } \\
1982\end{array}$ \\
\hline
\end{tabular}


Dictyota bartayresii Pachydictyol-A

Dictyota bartayresii $\beta$-dimethylsulfoniopropionate content

Dictyota bartayresii Fatty acids content

Dictyota ceylanica

Dictyota friabilis

Dolabelladienetriol

Dictyota friabilis

Phlorotannins

Dictyota pfaffii

10,18-diacetoxy-8hydroxy-2,

6-dolabelladiene,

10-acetoxy-

8,18_dihydroxy-2, 6-dolabelladiene,

$8,10,48$-trihydroxy-

2,6-dolabelladiene

Dictyota pfaffii

hydroxy-2,6-

dolabelladiene

\section{$25 \% \mathrm{NaOH}(\mathrm{w} / \mathrm{v}) \quad-$ and DMS: acrylic acid $(1: 1)$ \\ Trans-esterification - method}

Methanol extract

$\mathrm{CH}_{2} \mathrm{Cl}_{2}$ extract

$\mathrm{CH}_{2} \mathrm{Cl}_{2}: \mathrm{MeOH}$ 7:3 Herbivory deterrent and $\mathrm{MeOH} \quad$ against sea-urchins $(100 \%)$ HIV-1 in cervical tissue explants shrimps

MeOH:DCM (3:7), $\mathrm{MeOH}$ extracts
DCM:MeOH (3:1) Host and herbivory test

Methanol extract

Belize and Bahamas

Meixia, China

Hay, Duffy\&

Fenical, 1990

Bischoff et al., 1994

North Queensland, Australia

Gosh, Paul, De Nys, \& Magnusson, 2015

Thevenard island, Western Australia

Strong potential against

Prevent melanosis and extend shelf-life of Litopenaeus vannamei

Antiviral (HIV) and antiherpes virus activities
Atol das Rocas reef, Barbosa, Teixaira,

Rio Grande do Villaça, Pereira,

Norte State, Brazil et al., 2003 
Table 4 Overview of the biological activities recorded in the literature for Dictyotaceae species present in French Polynesia with indications of the type of molecules reported and the type of extraction used.-cont'd

Taxa

Dictyota pfaffi

Dolabellane diterpene

Crude extract

Dictyota pfaffii

Diterpene

Hexane extract

Dictyota pfaffii

Three new dolabellane diterpenes:

Dolabelladienols

A-C

Dictyota pfaffi

Dolabelladienetriol

Dictyota pfaffii

Dolabelladienetriol

Dictyota pfaffii

Dolabelladienetriol

Dictyota pfaffii
$\mathrm{CH}_{2} \mathrm{Cl}_{2}$ extract

$\mathrm{CH}_{2} \mathrm{Cl}_{2}$ extract

$\mathrm{CH}_{2} \mathrm{Cl}_{2}$ extract

Dolabelladienetriol
Biological activities

Herbivore deterrent against the sea-urchin Lytechinus variegatus, generalist fishes and not against crab Pachygrapsus transversus

Strong antifouling activity against the mussel Perna perna

Antiviral activity (HIV) and low cytotoxic against MT-2 lymphocyte tumor cells

Potential against HIV-1 on infected female mice

Low activity potential against HIV-1 on infected female mice

Inhibition of HIV-1 replication in human primary cells

Inhibition of HIV-1 on Brazil peripheral blood mononuclear cells

\section{References}

Atol das Rocas reef, Barbosa et al., 2004 Rio Grande do

Norte State, Brazil

Niterói, Rio de Janeiro, Brazil

Atol das Rocas reef, Pardo-Vargas et al., Rio Grande do Norte State, Brazil

Atol das Rocas reef, Rio Grande do Norte State, Brazil Atol das Rocas reef, Garrido et al., 2011 Rio Grande do Norte State, Brazil Brazil

Cirne-Santos et al., 2006

Cirne-Santos et al., 2008

Barbosa, Fleury, Da Gama, Teixeira, \& 2014

Garrido et al., 2017 Brazil 08 


\begin{tabular}{|c|c|c|c|c|c|}
\hline Dictyota pfaffii & Dolabelladienetriol & Two diterpenes & $\begin{array}{l}\text { Inhibition of HSV-1 } \\
\text { infection in Vero cells }\end{array}$ & Brazil & Abrantes et al., 2010 \\
\hline Dictyota pfaffii & Dolabelladienetriol & Dolabelladienetriol & $\begin{array}{l}\text { Inhibit Leishmania in } \\
\text { macrophages }\end{array}$ & Brazil & Soares et al., 2012 \\
\hline Dictyota spp. & $\begin{array}{l}\text { Dictyoepoxide, } \\
\text { pachydictyol-A, } \\
\text { pachydictyol-A } \\
\text { epoxide, acetals } 2 \mathrm{a} \text { and } \\
\text { 2b, dictyolactone, } \\
\text { acetyl dictyolal, } \\
\text { dictyoxide, dictyol B } \\
\text { acetate }\end{array}$ & $\begin{array}{l}\mathrm{CH}_{2} \mathrm{Cl}_{2} \text { extract and } \\
\text { Trimethylpentane }\end{array}$ & $\begin{array}{l}\text { Inhibition of vasopressin } \\
\text { binding to pig kidney }\end{array}$ & Bahia, Los Angeles & Patil et al., 1993 \\
\hline Dictyota spp. & $\begin{array}{l}\text { pachydictyol-A acetals } \\
2 \mathrm{a} \text { and } 2 \mathrm{~b}, \\
\text { dictyolactone }\end{array}$ & $\begin{array}{l}\mathrm{CH}_{2} \mathrm{Cl}_{2} \text { extract and } \\
\text { Trimethylpentane }\end{array}$ & Vasopressin antagonists & Bahia, Los Angeles & Patil et al., 1993 \\
\hline Dictyota spp. & $\begin{array}{l}\text { Diterpene alcohols } \\
\text { pachydictyol A and } \\
\text { dictyol E }\end{array}$ & Lipid-soluble extract & $\begin{array}{l}\text { Inhibit invertebrate } \\
\text { larvae settlement }\end{array}$ & $\begin{array}{l}\text { North Carolina, } \\
\text { USA }\end{array}$ & $\begin{array}{l}\text { Schmitt, Hay, \& } \\
\text { Lindquist, } 1995\end{array}$ \\
\hline Dictyota spp. & - & - & $\begin{array}{l}\text { Inhibit invertebrate } \\
\text { larvae settlement }\end{array}$ & Hawai'i & $\begin{array}{l}\text { Walters, Ruban, \& } \\
\text { Horton, } 1996\end{array}$ \\
\hline Dictyota spp. & Rich in terpenoid & - & $\begin{array}{l}\text { Defenses against } \\
\text { generalist herbivores }\end{array}$ & Worldwide & Hay, 1996 \\
\hline Dictyota spp. & Lipid-soluble chemical & - & $\begin{array}{l}\text { Defenses that deter } \\
\text { feeding by reef } \\
\text { herbivores }\end{array}$ & Worldwide & Hay, 1997 \\
\hline Dictyota spp. & Rich in terpenoid & - & $\begin{array}{l}\text { Defenses against } \\
\text { generalist herbivores }\end{array}$ & Worldwide & Fong \& Paul, 2011 \\
\hline Dictyota spp. & Dictyols & - & Herbivory deterrent & Worldwide & Paul \& Puglisi, 2004 \\
\hline
\end{tabular}


Table 4 Overview of the biological activities recorded in the literature for Dictyotaceae species present in French Polynesia with indications of the type of molecules reported and the type of extraction used.-cont'd

Taxa

Molecules reported

Extraction methods Biological activities

Location

References

Dictyota spp. Rich in terpenoid -

Dictyota spp. $\quad-$

Dictyota spp.

93 diterpenes and 15 skeletal classes

Dictyota spp.

Over 90 diterpenes and -

Dictyota spp. 233 diterpenes

Padina boergesenii Squalene

Padina boergesenii Triterpene

Padina boryana

Fucose, galactose, mannose, glucose and uronic acid residues

Padina boryana

Polysaccharides especially galactofucans

Padina boryana

High productivity of lipids and fatty acid methyl esters
Defenses against generalist herbivores

Increased mortality rates Long Key, Florida of coral recruits

Herbivory deterrent \& Worldwide use in

chemotaxonomy

Chemotaxonomy

$-$

N-hexane defatted methanol $(99.5 \%)$ crude extract

Methanol extract

Sulfated and

Acetylated fraction

Aqueous EtOH (70\%) with added $\mathrm{NaHCO}_{3}$

DCM:MeOH (2:1) with added $\mathrm{NaCl}$
Antioxidant and antiinflammatory

Enzyme inhibitory activities

Anticancer activity in vitro

Non-toxic and antitumor activity in vitro against DLD-1

human colon carcinoma cells

Candidate for investigation of biodiesel production
Tropical Atlantic American region

Vallim et al., 2005

Kuffner et al., 2006

Kelecom \& Teixeira, 1986

Worldwide

Worldwide

Teixeira \& Kelecom, 1988

Chen et al., 2018

Gulf of Mannar, Rajamani et al., 2018 India

Gulf of Oman $\quad$ Ali et al., 2017

Nhatrang Bay, Vietnam

Vietnam

Shevchenko et al., 2017

Red Sea at Jeddah Corniche, Saudi

Abomohra et al., Arabia 


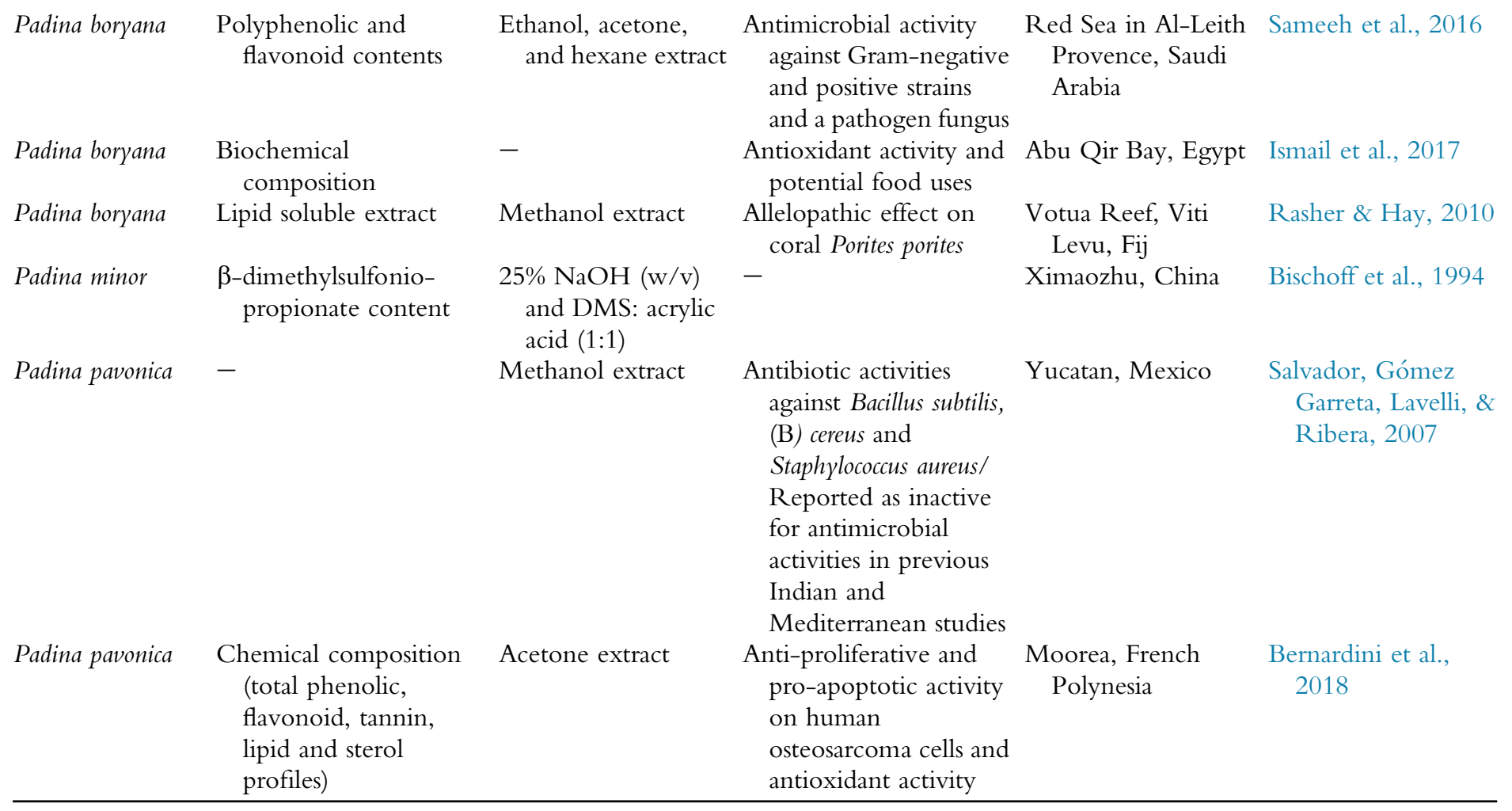


Table 4 Overview of the biological activities recorded in the literature for Dictyotaceae species present in French Polynesia with indications of the type of molecules reported and the type of extraction used.-cont'd

\begin{tabular}{|c|c|c|c|c|c|}
\hline Taxa & Molecules reported & Extraction methods & Biological activities & Location & References \\
\hline Padina sp. & $\begin{array}{l}\text { Contained additional } \\
\text { non-polyphenolic } \\
\text { non-polar secondary } \\
\text { metabolites }\end{array}$ & $\begin{array}{l}\text { Aqueous methanol } \\
\text { extract }\end{array}$ & Herbivory deterrent & Australia & $\begin{array}{l}\text { Steinberg \& Paul, } \\
1990\end{array}$ \\
\hline $\begin{array}{l}\text { Spatoglossum } \\
\text { asperum }\end{array}$ & - & Ethanol extract & $\begin{array}{l}\text { Cytotoxic activity on } \\
\text { Artemia salina (Brine } \\
\text { shrimp) }\end{array}$ & Karachi, Pakistan & Ara et al., 1999 \\
\hline $\begin{array}{l}\text { Spatoglossum } \\
\text { asperum }\end{array}$ & - & Ethanol extract & $\begin{array}{l}\text { Hypolipidaemic activity, } \\
\text { effect on cardiac and } \\
\text { liver enzymes }\end{array}$ & Karachi, Pakistan & Ara et al., 2002 \\
\hline $\begin{array}{l}\text { Spatoglossum } \\
\text { asperum }\end{array}$ & $\begin{array}{l}\text { Polyunsaturated fatty } \\
\text { acids }\end{array}$ & $\begin{array}{l}\text { Chloroform:MeOH } \\
\quad(1: 2)\end{array}$ & Nutritional significance & Gujarat, India & $\begin{array}{l}\text { Kumari, Kumar, } \\
\text { Gupta, Reddy, \& } \\
\text { Jha, } 2010\end{array}$ \\
\hline $\begin{array}{l}\text { Spatoglossum } \\
\text { asperum }\end{array}$ & Polyphenols & Methanol extract & $\begin{array}{l}\text { Antioxidant activity } \\
\text { (relatively high DPPH } \\
\text { activity) }\end{array}$ & Maharashtra, India & Vinayak et al., 2011 \\
\hline $\begin{array}{l}\text { Spatoglossum } \\
\text { asperum }\end{array}$ & Polyphenols & Methanol extract & $\begin{array}{l}\text { Cytotoxic activity } \\
\text { (highly toxic and } \\
\text { caused the death of } \\
\text { the brine shrimp) }\end{array}$ & Maharashtra, India & Vinayak et al., 2011 \\
\hline $\begin{array}{l}\text { Spatoglossum } \\
\text { asperum }\end{array}$ & $\begin{array}{l}\text { Fatty acids and lipid } \\
\text { hydroperoxydes } \\
\text { contents }\end{array}$ & $\begin{array}{l}\text { Chloroform:MeOH } \\
\quad(1: 2)\end{array}$ & - & $\begin{array}{l}\text { Saurashtra coast, } \\
\text { Gujarat, India }\end{array}$ & Kumari et al., 2012 \\
\hline
\end{tabular}




\begin{tabular}{|c|c|c|c|c|c|}
\hline $\begin{array}{l}\text { Spatoglossum } \\
\text { asperum }\end{array}$ & - & Ethanol extract & $\begin{array}{l}\text { Hypolipidemic } \\
\text { activities/decreases in } \\
\text { the serum total } \\
\text { cholesterol }\end{array}$ & - & Gade et al., 2013 \\
\hline $\begin{array}{l}\text { Spatoglossum } \\
\text { asperum }\end{array}$ & - & Methanol extract & $\begin{array}{l}\text { No antidiatom/ } \\
\text { antifouling activity }\end{array}$ & Mannar, India & Deepa et al., 2014 \\
\hline $\begin{array}{l}\text { Spatoglossum } \\
\text { asperum }\end{array}$ & - & $\begin{array}{l}\text { Chloroform:MeOH } \\
\quad(1: 1)\end{array}$ & $\begin{array}{l}\text { Maximum activity } \\
\text { against V.cholera and } \\
\text { K.pneumonia }\end{array}$ & Tamilnadu, India & $\begin{array}{l}\text { Sivakumar \& } \\
\text { Vignesh, } 2014\end{array}$ \\
\hline $\begin{array}{l}\text { Spatoglossum } \\
\text { asperum }\end{array}$ & - & Methanol extract & $\begin{array}{l}\text { Free radical scavenging } \\
\text { activity }\end{array}$ & Tamilnadu, India & $\begin{array}{l}\text { Pandithurai \& } \\
\quad \text { Murugesan, } 2014\end{array}$ \\
\hline $\begin{array}{l}\text { Spatoglossum } \\
\text { asperum }\end{array}$ & Polyphenols & $\begin{array}{l}\text { Sequential } \\
\text { extraction: } \\
\text { hexane, } \\
\text { dichloromethane, } \\
\text { ethyl acetate, and } \\
\text { methanol }\end{array}$ & $\begin{array}{l}\text { antitumor activity } \\
\text { against pancreatic } \\
\text { cancer }\end{array}$ & India & $\begin{array}{l}\text { Aravindan et al., } \\
2015\end{array}$ \\
\hline $\begin{array}{l}\text { Spatoglossum } \\
\text { asperum }\end{array}$ & - & Crude extract & $\begin{array}{l}\text { Antibacterial } \\
\text { (Staphylococcus aureus } \\
\text { and Escherichia coli) and } \\
\text { antifungal (Candida } \\
\text { albicans) activity }\end{array}$ & Mkomani, Kenya & Kaaria et al., 2015 \\
\hline $\begin{array}{l}\text { Spatoglossum } \\
\text { asperum }\end{array}$ & $\begin{array}{l}\text { Synthesis of silver } \\
\text { nanoparticules (Ag- } \\
\text { NPs), terpenoids and } \\
\text { phenols }\end{array}$ & $\begin{array}{l}\text { Chloroform:MeOH } \\
\quad(1: 1)\end{array}$ & $\begin{array}{l}\text { Antimicrobial activity } \\
\text { against plant diseases }\end{array}$ & Mannar, India & $\begin{array}{l}\text { Jothirethinam, } \\
\text { Prathilba, Shanti, } \\
\text { \& Arunkumar, } \\
2015\end{array}$ \\
\hline $\begin{array}{l}\text { Spatoglossum } \\
\text { asperum }\end{array}$ & - & Methanol extract & $\begin{array}{l}\text { Antimicrobial activity, } \\
\text { antibacterial activity } \\
\text { against } S \text {. aureus }\end{array}$ & $\begin{array}{l}\text { Mandapam coast, } \\
\text { India }\end{array}$ & $\begin{array}{l}\text { Pandithurai et al., } \\
\quad 2015\end{array}$ \\
\hline
\end{tabular}




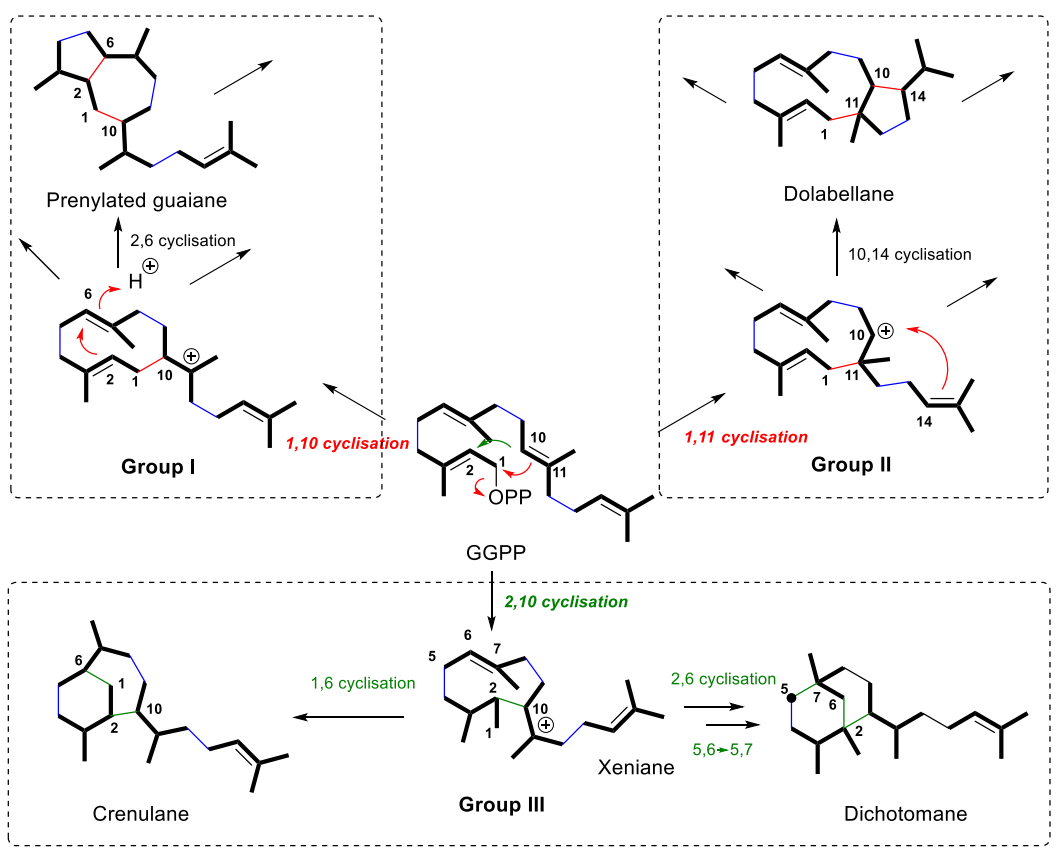

Fig. 3 Biosynthetic pathways of the three main groups of diterpenes isolated from various Dictyotaceae species.

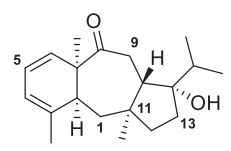

9-hydroxydolabelladien-6-one (1)

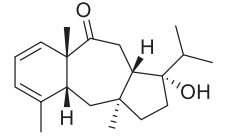

2

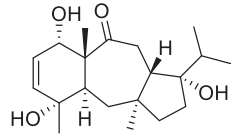

Trihydroxydolasta-2-en-6-one (3)

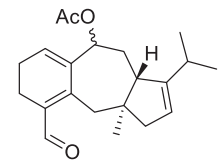

4

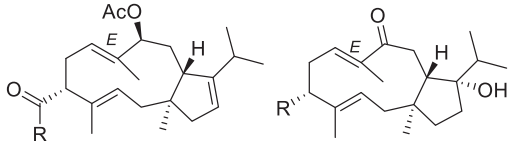

$5 \begin{array}{ll} & \mathrm{R} \\ 5 & \mathrm{H}\end{array}$
$7 \mathrm{R}$

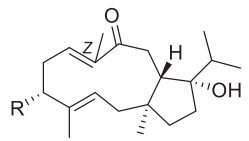

$\begin{array}{ll} & R \\ 9 & H \\ 10 & O A C\end{array}$

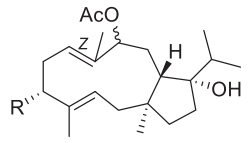

11

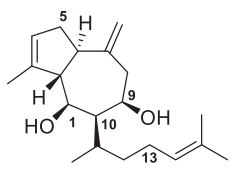

$8 \beta$-hydroxypachydictyol A (12)

Fig. 4 Structures of diterpenoids isolated from Dictyota bartayresiana. 
addition, $D$. bartayresiana extracts have shown a lethal activity against Artemia salina and Culex quinquefasciatus larvae (Antonysamy, Velayutham et al., 2015; Antonysamy, Thangiah, \& Irulappan, 2015), an ichthyotoxic effect against the fish Carassius auratus (De Lara-Isassi, Álvarez-Hernández, \& Collado-Vides, 2000), and antifouling properties against the diatom Navicula subinflata (Deepa, Srikumar, \& Padmakumar, 2014). It was also suggested that $D$. bartayresiana could be used as a natural healing drug and for general good health as some of its extracts were active against cancer cell lines (Antonysamy, Thangiah et al., 2015) and showed antioxidant activity (Palanisamy, Sellappa, \& Stella, 2010).

In the specific case of Dictyota ceylanica, only the phenolic contents (Van Hees, Olsen, Wernberg, Van Alstyne, \& Kendrick, 2017) and overall biochemical composition (total carbohydrates, total proteins, pigments, vitamins) (Chakraborty \& Santra, 2008) have been described. For Dictyota friabilis (previously known as Dictyota pfaffi), analyses of Brazilian specimens allowed the isolation of several dolabellane diterpenes displaying a broad range of biological activities (antiviral, cytotoxic, antifouling, etc.) (Table 4, Fig. 5). More specifically, the known dolabellane diterpene (group II) $\left(1 R^{\star}\right.$, $\left.2 E, 4 R^{\star}, 6 E, 8 S^{\star}, 10 S^{\star}, 11 S^{\star}, 12 R^{\star}\right)$-10,18-diacetoxy-8-hydroxy-2,6dolabelladiene was the first compound described (Fig. 5) as the main component of the organic extract (Barbosa, Teixaira, Villaça, Pereira, et al., 2003). Further studies on this species allowed to isolate four new dolabellanes $\left(1 R^{\star}, 2 E, 4 R^{\star}, 6 E, 8 S^{\star}, 10 S^{\star}, 11 S^{\star}, 12 R^{\star}-10\right.$-acetoxy-
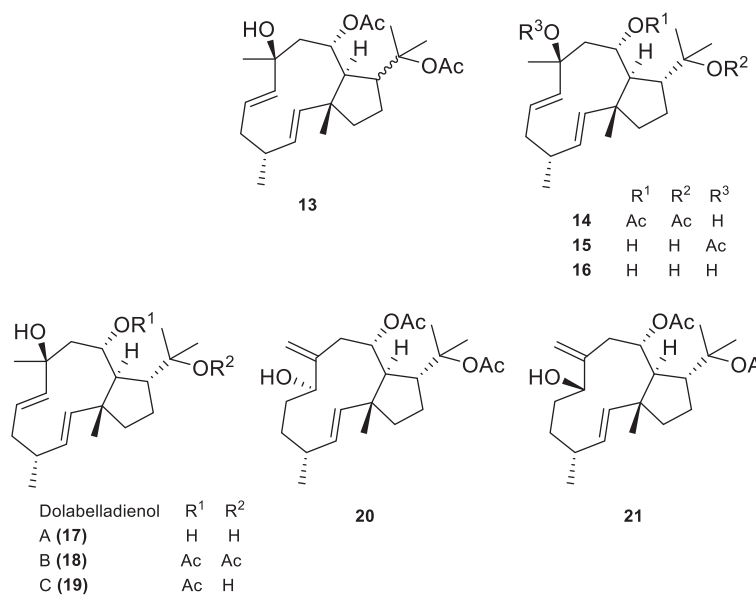

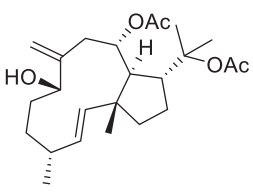

21

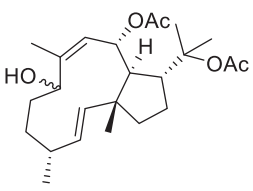

22

Fig. 5 Structures of diterpenoids isolated from Dictyota friabilis (syn. Dictyota pfaffii). 
8,18-dihydroxy-2,6-dolabelladiene, Dolabelladienol A, B, and C) as well as the known Dolabelladienetriol, and previously described from the digestive gland of Dolabella californica (Ireland \& Faulkner, 1977; Barbosa et al., 2004; Pardo-Vargas et al., 2014) (Fig. 5). Dolabelladienetriol, 10-acetoxy-8,18dihydroxy-2,6-dolabelladiene, and 10,18-diacetoxy-8-hydroxy-2,6-dolabelladiene showed potent in vitro antiviral activity against HIV-1, but Dolabelladienetriol was the only compound which inhibited the reverse transcriptase enzyme of the virus. The antiviral properties of Dolabelladienetriol were then deeply investigated (Abrantes et al., 2010; Cirne-Santos, Teixeira, Castello-Branco, Frugulhetti, \& Bou-Habib, 2006; Cirne-Santos et al., 2008; Garrido et al., 2017; Garrido et al., 2011; Stephens et al., 2017) and this diterpene was also shown to significantly inhibit the growth of Leishmania in macrophages (Soares et al., 2012). More recently, Dolabelladienols A and B were evaluated in the antiviral test against HIV-1 and were seen to be more active than Dolabelladienetriol (Pardo-Vargas et al., 2014). In another field of application, D. friabilis phlorotannins were assessed for their capacity to prevent the melanosis, quality changes and to prolong the shelf-life of iced Pacific white shrimps (Litopenaeus vannamei) (Sharifian, Shabanpour, Taheri, \& Kordjazi, 2019). Regarding Dictyota hamifera, we found no studies dedicated to chemodiversity or biological properties.

Lobophora. There are no studies dedicated to the evaluation of the phytochemical content and the subsequent biological properties of Lobophora pacifica. Considering the vast array of bioactivities exhibited by Lobophora spp. metabolites in general (Gaubert, Greff, Thomas, \& Payri, 2019; Vieira et al., 2015), it would be extremely relevant to investigate the chemodiversity associated to the species Lobophora in FP.

Padina. A minimal number of studies have isolated specialized metabolites from Padina. Fucoidans extracted from Vietnamese samples of Padina boryana were evaluated for their anticancer properties against colorectal carcinoma cells (Shevchenko et al., 2017; Usoltseva et al., 2018). Samples of Padina boryana from the Red Sea have been assessed for their potential in biodiesel production (Abomohra, El-Naggar, \& Baeshen, 2018) polyphenolic contents, and antimicrobial activity (Sameeh, Mohamed, \& Elazzazy, 2016), but also to determine their gross biochemical composition and their antioxidant properties (Ismail, El Zokm, \& El-Sayed, 2017). Rasher and Hay (2010) assessed the allelopathic effects of the lipid-soluble fraction of the methanolic extract of $P$. boryana against the coral Porites porites. An 
antioxidant and anti-inflammatory compound identified as squalene was isolated from Padina boergesenii samples collected in the Gulf of Mannar (India) (Rajamani, Balasubramanian, \& Thirugnanasambandan, 2018), while a new triterpene with several enzyme-inhibitory activities was described in samples of the same species from Oman (Ali et al., 2017). Many other studies were dedicated to the evaluation of a large number of biological activities (antioxidant, antidiabetic, hepatoprotective, etc.) of the extracts of $P$. boergesenii, mainly from samples from Mannar (Table 4). Dimethylsulfoniopropionate (DMSP) content was evaluated from Chinese samples of Padina minor (Bischoff et al., 1994), while several studies dealt with the biological properties of extracts coming from various collecting sites (Table 4). In Moorea, Padina pavonica (not recorded from Tahiti during our survey) was collected and tested for its pro-apoptotic activity on human osteosarcoma cells, a rare bone cancer condition (Bernardini, Minetti, Polizzotto, Biazzo, \& Santucci, 2018). The chemical composition of this species revealed interesting pharmacological and health-protecting activities and a great richness in flavonoids (Bernardini et al., 2018).

Spatoglossum. Spatoglossum asperum has been studied in the Indian Ocean exclusively (Pakistan, India, and Kenya) (Table 4). Ara, Sultana, Ehteshamul-Haque, Qasim, and Ahmad (1999) showed a positive response to the cytotoxic activity of $S$. asperum from Pakistan. This cytotoxicity was confirmed by Vinayak, Sabu, and Chatterji (2011) on brine shrimps. Ara, Sultana, Qasim, and Ahmad (2002) showed a hypolipidaemic effect and effects on cardiac and liver enzymes. Spatoglossum asperum has numerous other interesting biological activities including antibacterial activity against Staphylococcus aureus (Pandithurai, Murugesan, \& Sivamurugan, 2015), Escherichia coli (Kaaria, Wakibia, Matiru, Ndung'u, \& Bii, 2015), Bacillus cereus, Bacillus subtilis, Klebsiella pneumonia, Pseudomonas aeruginosa, and Salmonella typhi (Pandithurai et al., 2015; Sivakumar \& Vignesh, 2014), antifouling activities (Deepa et al., 2014), and antioxidant activities (Pandithurai \& Murugesan, 2014; Vinayak et al., 2011). Antimicrobial activities have been tested against plant diseases for agricultural uses (Jothirethinam, Prathilba, Shanti, \& Arunkumar, 2015). In 2015, S. asperum extracts revealed positive antitumoral effects (Aravindan, Ramraj, Somasundaram, Herman, \& Aravindan, 2015). Among the publications listed in Table 4, none gives precise chemical compositions of S. asperum. Vinayak et al. (2011) and Aravindan et al. (2015) believe that polyphenols are responsible for the cytotoxic and anti-tumoral activities; however, they did not refer to isolated molecules. 


\subsection{Applications}

\subsubsection{Human consumption}

The consumption of algae as food is the most significant market, representing about eighty percent of the world's algal production (FAO, 2016). According to a review by Zubia and Mattio (2019), four Dictyotaceae genera are used for food, mainly in the South Pacific Islands, including Dictyota, Dictyopteris (Dictyopteris plagiogramma "limu lipoa"; Hart, Ticktin, Kelman, Wright, \& Tabandera, 2014), Padina, and Spatoglossum. Other Dictyotaceae such as Padina and Dictyota are used for their medicinal properties and as a source of food in many Pacific Islands (Abbott, 1984; Conte \& Payri, 2002; Novaczek, 2001, pp. 1-48; South, 1993). Dictyota is eaten in various ways (seasoning, soup, etc.), and is also recognized as preventive medicine for heart diseases, stroke (algin compounds), and goiter (iodine content) (Novaczek, 2001, pp. 1-48). Padina is used to add flavor to dishes and is a good source of calcium (Novaczek, 2001, pp. 1-48). Dictyopteris plagiogramma is consumed traditionally in Hawaii (Abbott, 1984) and has a particularly strong and distinctive fragrance (due to dictyoterpenes; Moore, 1974), but this species is disappearing from the coast due to pollution (Hart et al., 2014).

In FP, seaweeds are still consumed today, particularly in the Marquesas and Austral islands with 11 species recorded (Conte \& Payri, 2002, 2006; De Gaillande, Payri, Remoissenet, \& Zubia, 2017), six of them belonging to the genus Caulerpa. In most of the Islands, this tradition has been lost, except in the Marquesas and the Austral archipelagos where Caulerpa chemnitzia (= C. racemosa var. turbinata) known as sea grapes ("remu" or "imu topua" in polynesian language) is consumed regularly (De Gaillande et al., 2017). In recent years, seaweed consumption has become more popular, and the French Polynesian Government wants to diversify the offer through the development of seaweed farming for Caulerpa spp. and a few red algae (Gracilaria spp., Gelidiella acerosa, Acanthophora spicifera). The development of Dictyotaceae species consumption like Dictyota, Padina or Spatoglossum could also be an exciting option to diversify the market.

\subsubsection{Animal nutrition}

A large proportion of methane emitted into the atmosphere derives from agriculture and specifically ruminant enteric fermentation which contributes approximately to $28 \%$ of global anthropogenic $\mathrm{CH}_{4}$ emissions (Beauchemin, Kreuzer, O'Mara, \& McAllister, 2008). Feed management and 
additives such as high-quality forages, grains, ionophores, fats, yeasts, enzymes, microbes, plant extracts, and algae have the potential for $\mathrm{CH}_{4}$ abatement (Beauchemin, Mc Allister, \& McGinn, 2009). Algae products can improve ruminant health and productivity, increase feed quality, and inhibit methanogenesis (Holdt \& Kraan, 2011; Kinley, De Nys, Vucko, Machado, \& Tomkins, 2016). Kinley et al. (2016) showed that Asparagopsis induces near elimination of methane in vitro, and Machado, Magnusson, Paul, De Nys, and Tomkins (2014) found that the brown algae Dictyota spp. can reduce methane production by over $92 \%$ compared to controls.

Many experiments are currently underway in the field of aquaculture, for the incorporation of algae in shrimp and fish feeds (Nelson, Glenn, Conn, Walsh, \& Akutagawa, 2001; Reverter, Bontemps, Lecchini, Banaigs, \& Sasal, 2014). These algae or seaweed extracts are used either to replace proteins of animal origin either for their probiotic or antimicrobial effects, usually in the context of Integrated Multi-Trophic Aquaculture (IMTA) projects. In FP, emerging Platax orbicularis (orbicular batfish) aquaculture is affected by bacterial infections causing severe mortality episodes. Effective solutions are investigated to find natural bioactive compounds to counteract the infections caused principally by Tenacibaculum maritimum and Vibrio harveyi, and Reverter et al. (2016) demonstrated the promising results obtained with the Rhodophyta Asparagopsis taxiformis. Due to their antiviral and antimicrobial activities, their abundance, availability, and accessibility, Dictyotaceae species represent an equally interesting group to consider. Our research unit in Tahiti (UMR-EIO) is currently investigating the efficiency of French Polynesian Dictyota bartayresiana, Dictyota hamifera, and Spatoglossum asperum extracts against the pathogens $V$. harveyi and T. maritimum.

\subsubsection{Health care, medicinal, pharmaceutical, and cosmetic properties}

The use of macroalgae in cosmetics is quickly expanding as they represent a natural and active environmental resource. Several species are already used by several cosmetic industries in hair care, skin whitening, anti-aging, moisturizers, or in sunscreens (Ariede et al., 2017), but there is no reference on the use of tropical species for cosmetics in the literature. As previously discussed in section 4.1 and presented in Table 4, Dictyotaceae species synthesize a wide range of molecules with specific biological activities that could be used as active ingredients in cosmetics or health industries. For instance, Fayad et al. (2017) highlighted the promising activity of Padina pavonica 
for the inhibition of hyalurosidase activity, which is expected to delay skin aging. Spatoglossum asperum also showed hypolipidic effects interesting against cholesterol disease (Gade, Tulasi, \& Bhai, 2013). Other species of Dictyotaceae could be relevant for the health industry for their antiviral, antimicrobial, antioxidant, anti-inflammatory, and anti-cancer activities (Table 4), which are significant medical research challenges. According to our literature review, it is clear that the Dictyotaceae species of FP are a potential source of new exciting and potentially unique molecules that could be extremely useful for the cosmetic and health industry. However, although the potentials are high, only limited research is available that has explored specifically the diversity of the French Polynesian Dictyotaceae molecules and their associated biological potential.

\subsubsection{Agriculture}

Seaweeds can be used for many agricultural applications including biofertilizers, soil conditioners, and enhancers because of their high quantities of micro- and macronutrients, vitamins, amino acids, and growth regulators (Arioli, Mattner, \& Winberg, 2015; Kumar \& Sahoo, 2011; N’Yeurt \& Iese, 2015a). Seaweed extracts represent a major opportunity to significantly enhance crop production and resistance to stress and disease (Arioli et al., 2015). Brown algae are particularly useful fertilizers (Arioli et al., 2015). Experiments in Fiji have demonstrated the potential of both Sargassum polycystum and Gracilaria edulis as excellent liquid fertilizers for a variety of common Pacific crops (unpublished results, N'Yeurt, pers. com.). Brown-algae based fertilizers contain alginates and sulfated polysaccharides, their chelating properties combined with metal ions in the soil form chelates that absorb moisture and improve the growth of soil bacteria (Cardozo et al., 2007; Khan et al., 2009). In FP, agronomical enrichment trials were conducted using drifting brown algae (S. pacificum and T. ornata) as organic additives (Zubia et al., 2014). This study demonstrated that low supplements of drift algae (1 and 3\%) to plant compost significantly improved maize growth (stems length, aerial plants dry mass, and roots dry mass). In Tuvalu, farmers successfully use additives made of dried Sargassum polycystum on their crops (N'Yeurt \& Iese, 2015b). Although we did not find studies on potential uses of Dictyotaceae species for agricultural purposes during our review, they could represent good candidates to develop eco-friendly fertilizer and additives of farming practices, in particular, to fight against phytopathogens due to their strong antimicrobial activities (Table 4). 


\section{Scope for future research}

This paper represents the first detailed assessment of the Dictyotaceae family in FP. It reviews and supplements the existing knowledge on the diversity, ecology, chemodiversity, and potential economic applications of these species. Molecular analyses of the different genera are underway and will undoubtedly increase the known diversity of the Dictyotaceae family (44 species across all archipelagos to date). These results will be crucial for a better understanding of the diversity patterns in FP, and biogeographical studies in the Indo-Pacific, which are currently constrained by overlooked cryptic diversity (Vieira et al., 2017). Our research project was motivated by the observation of increasing amounts of Dictyotaceae species (especially Dictyota bartayresiana and Spatoglossum asperum) on the reefs of Tahiti Island over the past decade. However, our results do not indicate the occurrence of proliferation events, as the abundances we measured were relatively low (cover $<10 \%$ ) on all reefs surveyed throughout the year. Despite this result, and in light of our review, we argue here that monitoring Dictyotaceae species should be continued because of the potential negative impact they may have on coral health, particularly during periods of intense bleaching (see Section 3.2.2). Proliferations events were mainly triggered by increased temperatures, nutrients, and/or $\mathrm{pH}$ or biotic factors such as a decrease in herbivores which negatively impacted coral cover and favored the more resistant and opportunistic Dictyotaceae species (see Section 3). As Tahiti's coral reefs are subject to significant anthropogenic and environmental pressures (Andréfouët \& Adjeroud, 2019), we believe that further studies are needed to better characterize the ecological dynamics of Dictyotacae, particularly biotic factors. These data will be critical to design appropriate management policies and avoid future additional proliferations on the reefs of Tahiti. Finally, Dictyotaceae species represent promising resources for many biotechnological applications (human and animal nutrition, agriculture, health, cosmetic), most of which could be developed in FP. However, further studies are needed to characterize the chemodiversity of local populations and assess which economic sectors would be most suited for FP.

\section{Acknowledgments}

This work is part of the Ph.D. thesis of Tohei Theophilus. We are very thankful to the University of French Polynesia and the Délégation à la Recherche de Polynésie française for their financial support without which the research program DIVECOBAL would not have been possible. 


\section{Appendix A. Supplementary data}

Supplementary data to this article can be found online at https://doi. org/10.1016/bs.abr.2019.12.001.

\section{References}

Abbott, I. A. (1984). Limu: An ethnobotanical study of some Hawaiian seaweeds. National Tropical Botanical Garden.

Abomohra, A. E.-F., El-Naggar, A. H., \& Baeshen, A. A. (2018). Potential of macroalgae for biodiesel production: Screening and evaluation studies. Journal of Bioscience and Bioengineering, 125(2), 231-237.

Abrantes, J. L., Barbosa, J., Cavalcanti, D., Pereira, R. C., Fontes, F. C. L., Teixeira, V. L., et al. (2010). The effects of the diterpenes isolated from the Brazilian brown algae Dictyota pfaffi and Dictyota menstrualis against the herpes simplex type-1 replicative cycle. Planta Medica, 76, 339-344.

Adam, T. C., Schmitt, R. J., Holbrook, S. J., Brooks, A. J., Edmunds, P. J., Carpenter, R. C., et al. (2011). Herbivory, connectivity, and ecosystem resilience: Response of a coral reef to a large-scale perturbation. PLoS One, 6(8), e23717.

Ali, L., Khan, A. L., Al-Broumi, M., Al-Harrasi, R., Al-Kharusi, L., Hussain, J., et al. (2017). New enzyme-inhibitory triterpenoid from marine macro brown alga Padina boergesenii Allender \& Kraft. Marine Drugs, 15(19), 1-8.

Andréfouët, S., \& Adjeroud, M. (2019). French Polynesia. In World seas: An environmental evaluation (pp. 827-854). Academic Press.

Antonysamy, J. M. A., Thangiah, S., \& Irulappan, R. (2015). Green synthesis of silver nanoparticles using Dictyota bartayresiana J.V. Lamouroux and their cytotoxic potentials. International Biological and Biomedical Journal, 1(3), 112-118.

Antonysamy, J. M. A., Velayutham, K., Mani, N., Thangaiah, S., \& Irullappan, R. (2015). Antibacterial, cytotoxic and larvicidal potential of Dictyota bartayresiana Lamour. Journal of Coastal Life Medicine, 3(5), 352-355.

Ara, J., Sultana, V., Ehteshamul-Haque, S., Qasim, R., \& Ahmad, V. U. (1999). Cytotoxic activity of marine macroalgae on Artemia salina (brine shrimp). Phytotherapy Research, 13, 304-307.

Ara, J., Sultana, V., Qasim, R., \& Ahmad, V. U. (2002). Hypolipidaemic activity of seaweed from Karachi coast. Phytotherapy Research, 16(5), 479-483.

Aravindan, S., Ramraj, S. K., Somasundaram, S. T., Herman, T. S., \& Aravindan, N. (2015). Polyphenols from marine brown algae target radiotherapy-coordinated EMT and stemness-maintenance in residual pancreatic cancer. Stem Cell Research and Therapy, 6(182), $1-14$.

Ariede, M. B., Candido, T. M., Jacome, A. L. M., Valesco, M. V. R., De Carvalho, J. C. M., \& Baby, A. R. (2017). Cosmetic attributes of algae - A review. Algae Research, 25, 483487.

Arioli, T., Mattner, S. W., \& Winberg, P. C. (2015). Applications of seaweed extracts in Australian agriculture: Past, present and future. Journal of Applied Phycology, 27(5), 2007-2015.

Barbosa, J. P., Fleury, B. G., Da Gama, B. A. P., Teixeira, V. L., \& Pereira, R. C. (2007). Natural products as antifoulants in the Brazilian brown alga Dictyota pfaffii (Phaeophyta, Dictyotales). Biochemical Systematics and Ecology, 35, 549-553.

Barbosa, J. P., Pereira, R. C., Abrantes, J. L., Cirne-Santos, C. C., Rebello, M. A., Frugulhetti, I. C. P., et al. (2004). In vitro antiviral diterpenes from the Brazilian brown alga Dictyota pfaffii. Planta Medica, 70, 856-860. 
Barbosa, J. P., Teixeira, V. L., Villaça, R. C., Pereira, H. S., Abrantes, J. L., \& Frugulhetti, I. C. N. P. (2003). A dolabellane diterpene from de Brazilian brown alga Dictyota pfaffii. Biochemical Systematics and Ecology, 31, 1451-1453.

Barott, K. L., Rodriguez-Mueller, B., Youle, M., Marhaver, K. L., Vermeij, M. J. A., Smith, J. E., et al. (2011). Microbial to reef scale interactions between the reef-building coral Montastraea annularis and benthic algae. Proceedings of the Royal Society B: Biological Sciences, 279, 1655-1664.

Beach, K., Walters, L., Borgeas, H., Smith, C., Coyer, J., \& Vroom, P. (2003). The impact of Dictyota spp. on Halimeda populations of Conch Reef, Florida Keys. Journal of Experimental Marine Biology and Ecology, 297, 141-159.

Beauchemin, K. A., Kreuzer, M., O’Mara, F., \& McAllister, T. A. (2008). Nutritional management for enteric methane abatement: A review. Australian Journal of Experimental Agriculture, $48,21-27$.

Beauchemin, K. A., McAllister, T. A., \& McGinn, S. M. (2009). Dietary mitigation of enteric methane from Cattle. CAB Reviews: Perspectives in Agriculture, Veterinary Science, Nutrition and Natural Resources, 4, 1-18.

Bernardini, G., Minetti, M., Polizzotto, G., Biazzo, M., \& Santucci, A. (2018). Pro-apoptotic activity of French Polynesian Padina pavonica extract on human osteosarcoma cells. Marine Drugs, 16(12), 504.

Bheemasankara Rao, C., Trimurtulu, G., Sreedhara, C., Ventaka Rao, D., Bobzin, S. C., \& Faulkner, D. J. (1994). Diterpenes from the brown alga Dictyota bartayresiana. Phytochemistry, 37(2), 509-513.

Bischoff, B., Karsten, U., Daniel, C., Kuck, K., Xia, B., \& Wiencke, C. (1994). Preliminary assessment of the $\beta$-dimethylsulfoniopropionate (DMSP) content of macroalgae from the tropical island of Hainan (People's Republic of China). Australian Journal of Marine and Freshwater Research, 45(7), 1329-1336.

Bischof, K., Gómez, I., Molis, M., Hanelt, D., Karsten, U., Lüder, U., et al. (2006). Ultraviolet radiation shapes seaweed communities. Reviews in Environmental Science and Biotechnology, 5, 141-166.

Bittick, S. J., Clausing, R. J., Fong, C. R., Scoma, S. R., \& Fong, P. (2019). A rapidly expanding macroalga acts as a foundational species providing trophic support and habitat in the South Pacific. Ecosystems, 22(1), 165-173.

Bittner, L., Halary, S., Payri, C., Cruaud, C., De Reviers, B., Lopez, P., et al. (2010). Some considerations for analyzing biodiversity using integrative metagenomics and gene networks. Biology Direct, 5, 47.

Bittner, L., Payri, C. E., Couloux, A., Cruaud, C., De Reviers, B., \& Rousseau, F. (2008). Molecular phylogeny of the Dictyotales and their position within the brown algae, based on nuclear, plastidial and mitochondrial sequence data. Molecular Phylogenetics and Evolution, 49, 211-226.

Bonaldo, R. M., \& Hay, M. E. (2014). Seaweed-coral interactions: Variance in seaweed allelopathy, coral susceptibility, and potential effects on coral resilience. PLoS One, 9(1). e85786, 1-12.

Bory De Saint-Vincent, J. B. G. M. (1828). Cryptogamie. In L. I. Duperrey (Ed.), Voyage Autour du Monde exécuté par ordre du Roi, sur la corvette de sa Majesté, La Coquille, pendant les années 1822, 1823, 1824 et 1825 (pp. 1-136). Paris: Arthus Bertrand.

Brown, K. T., Bender-Champ, D., Kubicek, A., van der Zande, R., Achlatis, M., HoeghGuldberg, O., et al. (2018). The dynamics of coral-algal interactions in space and time on the southern Great Barrier Reef. Frontiers in Marine Science, 5, 181.

Camoin, G., Cabioch, G., Eisenhauer, A., Braga, J.-C., Hamelin, B., \& Lericolais, G. (2006). Environmental significance of microbialites in reef environments during the last deglaciation. Sedimentary Geology, 185, 277-295. 
Camoin, G. F., Gautret, P., Montaggioni, L. F., \& Cabioch, G. (1999). Nature and environmental significance of microbialites in Quaternary reefs: The Tahiti paradox. Sedimentary Geology, 126, 271-304.

Caragnano, A., Foetisch, A., Maneveldt, G. W., Millet, L., Liu, L. C., Lin, S. M., et al. (2018). Revision of Corallinaceae (Corallinales, Rhodophyta): Recognizing Dawsoniolithon gen. nov., Parvicellularium gen. nov. and Chamberlainoideae subfam. nov. containing Chamberlainium gen. nov. and Pneophyllum. Journal of Phycology, 54(3), 391-409.

Cardozo, K. H. M., Guaratini, T., Barros, M. P., Falcao, V. R., Tonon, A. P., Lopes, N. P., et al. (2007). Metabolites from algae with economical impact. Comparative Biochemistry Physiology C-Toxicology Pharmacology, 146, 60-78.

Carroll, A. R., Copp, B. R., Davis, R. A., Keysers, R. A., \& Prinsep, M. R. (2019). Marine natural products. Natural Product Reports, 36, 122-173.

Chakraborty, S., \& Santra, S. C. (2008). Biochemical composition of eight benthic algae collected from Sunderban. Indian Journal of Marine Sciences, 37(3), 329-332.

Chaves, L. T. C., Pereira, P. H. C., \& Feitosa, J. L. L. (2013). Coral reef fish association with macroalgal beds on a tropical reef system in North-eastern Brazil. Marine and Freshwater Research, 64(12), 1101-1111.

Chen, J., Li, H., Zhao, Z., Xia, X., Li, B., Zhang, J., et al. (2018). Diterpenes from the marine algae of the genus Dictyota. Marine Drugs, 16(159), 1-25.

Cirne-Santos, C. C., Souza, T. M. L., Teixeira, V. L., Fontes, C. F. L., Rebello, M. A., Castello-Branco, L. R. R., et al. (2008). The dolabellane diterpene Dolabelladienetriol is a typical noncompetitive inhibitor of HIV-1 reverse transcriptase enzyme. Antiviral Research, 77, 64-71.

Cirne-Santos, C. C., Teixeira, V. L., Castello-Branco, L. R., Frugulhetti, I. C. P. P., \& BouHabib, D. C. (2006). Inhibition of HIV-1 Replication in human primary cells by a dolabellane diterpene isolated from the marine algae Dictyota pfaffii. Planta Medica, 72, 295299.

Clausing, R. J., \& Fong, P. (2016). Environmental variability drives rapid and dramatic changes in nutrient limitation of tropical macroalgae with different ecological strategies. Coral Reefs, 35, 669-680.

Conte, E., \& Payri, C. E. (2002). La consommation des algues en Polynésie française : Premiers résultats d'une enquête. Le Journal de la Société des Océanistes, 114-115, 165-172.

Conte, E., \& Payri, C. E. (2006). Present day consumption of edible algae in French Polynesia: A study of the survival of pre-European practices. Journal of the Polynesian Society, 115(1), 77-93.

De Clerck, O., Leliaert, F., Verbruggen, H., Lane, C. E., De Paula, J. C., Payo, D. A., et al. (2006). A revised classification of the dictyotaceae (Dictyotales, Phaeophyceae) based on $r b c \mathrm{~L}$ and 26S Ribosomal DNA sequence analyses. Journal of Phycology, 42(6), 1271-1288.

De Gaillande, C., Payri, C., Remoissenet, G., \& Zubia, M. (2017). Caulerpa consumption, nutritional value and farming in the Indo-Pacific region. Journal of Applied Phycology, 29(5), 2249-2266.

De Lara-Isassi, G., Álvarez-Hernández, S., \& Collado-Vides, L. (2000). Ichtyotoxic activity of extracts from Mexican marine macroalgae. Journal of Applied Phycology, 12, 45-52.

De Paula, J. C., Vallim, M. A., \& Teixeira, V. L. (2011). What are and where are the bioactive terpenoids metabolites from Dictyotaceae (Phaeophyceae). Revista Brasileira de Farmacognosia Brazilian Journal of Pharmacognosy, 21(2), 216-228.

Deepa, S., Srikumar, M., \& Padmakumar, K. P. (2014). Antifouling potential of selected macroalgae from the Gulf of Mannar, India. International Journal of Bioassays, 3(11), 3479-3487.

Del Monaco, C., Hay, M. E., Gartrell, P., Mumby, P. J., \& Diaz-Pulido, G. (2017). Effects of ocean acidification on the potency of macroalgal allelopathy to a common coral. Scientific Reports, 7(41053), 1-10. 
Diaz-Pulido, G., Harii, S., McCook, L. J., \& Hoegh-Guldberg, O. (2010). The impact of benthic algae on the settlement of a reef-building coral. Coral Reefs, 29, 203-208.

Diaz-Pulido, G., Villamil, L., \& Almanza, V. (2007). Herbivory effects on the morphology of the brown alga Padina boergesenii (Phaeophyta). Phycologia, 46(2), 131-136.

Dijoux, L., Viard, F., \& Payri, C. (2014). The more we search, the more we find: Discovery of a new lineage and a new species complex in the genus Asparagopsis. PLoS One, 9(7). e103826, 1-13.

Done, T. J. (1992). Phase shifts in coral reef communities and their ecological significance. Hydrobiologia, 247(1-3), 121-132.

Duffy, J. E., \& Harvilicz, A. M. (2001). Species-specific impacts of grazing amphipods in an eelgrass-bed community. Marine Ecology Progress Series, 223, 201-211.

Enochs, I. C., Manzello, D. P., Donham, E. M., Kolodziej, G., Okano, R., Johnston, L., et al. (2015). Shift from coral to macroalgae dominance on a volcanically acidified reef. Nature Climate Change, 5(12), 1083.

Fabricius, K. E. (2005). Effects of terrestrial runoff on the ecology of corals and coral reefs: Review and synthesis. Marine Pollution Bulletin, 50, 125-146.

FAO. (2016). The State of World Fisheries and Aquaculture 2016. Contributing to food security and nutrition for all. Rome, $200 \mathrm{p}$.

Faure, G. (1989). Degradation of coral reefs at Moorea island (French Polynesia) by Acanthaster planci. Journal of Coastal Research, 5, 295-306.

Fayad, S., Nehmé, R., Tannoury, M., Lesellier, E., Pichon, C., \& Morin, P. (2017). Macroalga Padina pavonica water extracts obtained by pressurized liquid extraction and microwave-assisted extraction inhibit hyaluronidase activity as shown by capillary electrophoresis. Journal of Chromatography A, 1497, 19-27.

Fong, C. R. (2015). An experimental assessment of herbivory and nutrient effects on a smallscale in a coral reef macroalgal community. Aquatic Botany, 123, 1-5.

Fong, P., Frazier, N. M., Tompkins-Cook, C., Muthukrishnan, R., \& Fong, C. R. (2016). Size matters: Experimental partitioning of the strength of fish herbivory on a fringing coral reef in Moorea, French Polynesia. Marine Ecology, 37, 933-942.

Fong, P., \& Paul, V. J. (2011). Coral reef algae. Coral reefs: An ecosystem in transition. New York.

Fulton, C. J., Depczynski, M., Holmes, T. H., Noble, M. M., Radford, B., Wernberg, T., et al. (2014). Sea temperature shapes seasonal fluctuations in seaweed biomass within the Ningaloo coral reef ecosystem. Limnology and Oceanography, 59(1), 156-166.

Gade, R., Tulasi, M. S., \& Bhai, V. A. (2013). Seaweeds: A novel biomaterial. International Journal of Pharmacy and Pharmacentical Sciences, 5(2), 40-44.

Garrido, V., Barros, C., Melchiades, V. A., Fonseca, R. R., Pinheiro, S., Ocampo, P., et al. (2017). Subchronic toxicity and anti-HSV-1 activity in experimental animal of dolabelladienetriol from the seaweed, Dictyota pfaffii. Regulatory Toxicology and Pharmacology, 86, 193-198.

Garrido, V., Teixeira, G. A. P. B., Teixeira, V. L., Ocampo, P., Ferreira, W. J., Cavalcanti, D. N., et al. (2011). Evaluation of the acute toxicity of dolabelladienotriol, a potential antiviral from the brown alga Dictyota pfaffii, in BALB/c mice. Revista Brasileira de Farmacognosia, 21(2), 209-215.

Gaubert, J., Greff, S., Thomas, O. P., \& Payri, C. E. (2019). Metabolomic variability of four macroalgal species of the genus Lobophora using diverse approaches. Phytochemistry, 162, $165-172$.

Gillespie, T. W., Foody, G. M., Rocchini, D., Giorgi, A. P., \& Saatchi, S. (2008). Measuring and modelling biodiversity from space. Progress in Physical Geography, 32, 203-221.

Gleason, D. F., \& Wellington, G. M. (1993). Ultraviolet radiation and coral bleaching. Nature, $365,836-838$. 
Goldberg, N. A., \& Kendrick, G. A. (2004). Effects of island groups, depth, and exposure to ocean waves on subtidal macroalgal assemblages in the Recherche Archipelago, Western Australia. Journal of Phycology, 40, 631-641.

Gómez Garreta, M., Rull, J., \& Ribera Siguán, M. A. (2007). On the presence of fertile gametophytes of Padina pavonica (Dictyotales, Phaeophyceae) from the Iberian coasts. Anales del Jardín Botánico de Madrid, 64(1), 27-33.

Gosch, B. J., Paul, N. A., De Nys, R., \& Magnusson, M. (2015). Spatial, seasonal, and within-plant variation in total fatty acid content and composition in the brown seaweeds Dictyota bartayresii and Dictyopteris australis (Dictyotales, Phaeophyceae). Journal of Applied Phycology, 27(4), 1607-1622.

Guiry, M. D., \& Guiry, G. M. (2019). AlgaeBase. Galway: World-wide electronic publication, National University of Ireland.

Hart, G. M., Ticktin, T., Kelman, D., Wright, A. D., \& Tabandera, N. (2014). Contemporary gathering practice and antioxidant benefit of wild seaweeds in Hawai'i. Economy Botany, 68(1), 30-43.

Hay, M. E. (1991). Fish-seaweed interactions on coral reefs: Effects of herbivorous fishes and adaptations of their prey. In The ecology of fishes on coral reefs (pp. 96-119). San Diego: Academic Press.

Hay, M. E. (1996). Marine chemical ecology: what's known and what's next? Journal of Experimental Marine Biology and Ecology, 200, 103-134.

Hay, M. E. (1997). The ecology and evolution of seaweed-herbivore interactions on coral reefs. Coral Reefs, 16, 67-76.

Hay, M. E., Duffy, J. E., \& Fenical, W. (1990). Host-plant specialization decreases Predation on a marine amphipod: An herbivore in plant's clothing. Ecology, 71(2), 733-743.

Heindel, K., Birgel, D., Brunner, B., Thiel, V., Westphal, H., Gischler, E., et al. (2012). Postglacial microbialite formation in coral reefs of the Pacific, Atlantic, and Indian Oceans. Chemical Geology, 304-305, 117-130.

Herren, L. W., Walters, L. J., \& Beach, K. S. (2006). Fragmentation generation, survival, and attachment of Dictyota spp. at Conch Reef in the Florida Keys, USA. Coral Reefs, 25, 287-295.

Ho, M., \& Carpenter, R. C. (2017). Differential growth responses to water flow and reduced $\mathrm{pH}$ in tropical marine macroalgae. Journal of Experimental Marine Biology and Ecology, 491, $58-65$.

Holbrook, S. J., Schmitt, R. J., Adam, T. C., \& Brooks, A. J. (2016). Coral reef resilience, tipping points and the strength of herbivory. Nature, 6(35817), 1-11.

Holdt, S. L., \& Kraan, S. (2011). Bioactive compounds in seaweed: Functional food applications and legislation. Journal of Applied Phycology, 23, 543-597.

Hughes, T. P. (1994). Catastrophes, phase shifts, and large-scale degradation of a -Caribbean coral reef. Science, 265(5178), 1547-1551.

Hughes, T. P., Graham, N. A. J., Jackson, J. B. C., Mumby, P. J., \& Steneck, R. S. (2010). Rising to the challenge of sustaining coral reef resilience. Trends in Ecology and Evolution, 25(11), 634-642.

Hughes, T. P., Rodrigues, M. J., Bellwood, D. R., Ceccarelli, D., Hoegh-Guldberg, O., McCook, L., et al. (2007). Phase shifts, herbivory, and the resilience of coral reefs to climate change. Current Biology, 17, 360-365.

Ireland, C., \& Faulkner, D. J. (1977). Diterpenes from Dolabella californica. Journal of Organic Chemistry, 42(19), 3157-3162.

Ismail, M. M., El Zokm, G. M., \& El-Sayed, A. M. (2017). Variation in biochemical constituents and master elements in common seaweeds from Alexandria coast, Egypt, with special reference to their antioxidant activity and potential food uses: Prospective equations. Environmental Monitoring and Assessment, 189, 175-648. 
Jothirethinam, A., Prathiba, S., Shanti, N., \& Arunkumar, K. (2015). Green synthesized silver nanoparticles prepared from the antimicrobial Crude extracts of two brown seaweeds against plant pathogens. American Journal of Nanotechnology, 6(2), 31-39.

Kaaria, P., Wakibia, J., Matiru, V., Ndung'u, M., \& Bii, C. (2015). Antimicrobial screening of marine endophytes and epiphytes isolated from marine algae of Kenyan Indian Ocean. Journal of Applied and Environmental Microbiology, 3(3), 70-74.

Kamat, S. Y., Wahidulla, S., D’Souza, L., Naik, C. G., Ambiye, V., Bhakuni, D. S., et al. (1992). Bioactivity of marine organisms VI. Antiviral evaluation of marine algal extracts from the Indian coast. Botanica Marina, 35, 161-164.

Kashiwagi, M., Mynderse, J.-S., Moore, R. E., \& Norton, T. R. (1980). Antineoplastic evaluation of pacific basin marine algae. Journal of Pharmaceutical Sciences, 69(6), 735-738.

Kaullysing, D., Gopeechund, A., Mattan-Moorgawa, S., Taleb-Hossenkhan, N., Kulkarni, B., \& Bhagooli, R. (2016). Increased density of the corallivore Drupella cornus on Acropora muricata colonies overgrown by Padina boryana. In Proceedings of the 13th international coral reefs symposium, Hawaii, USA (pp. 288-304).

Kayal, M., Vercelloni, J., De Loma, T. L., Bosserelle, P., Chancerelle, Y., Geoffroy, S., et al. (2012). Predator crown-of-thorns starfish (Acanthaster planci) outbreak, mass mortality of corals, and cascading effects on reef fish and benthic communities. PLoS One, 7(10), e47363, 1-9.

Kelecom, A., \& Teixeira, V. L. (1986). Diterpenes of marine brown algae of the family dictyotaceae: Their possible role as defense compounds and their use in chemotaxonomy. The Science of the Total Environment, 58(1-2), 109-115.

Khan, W., Rayirath, U. P., Subramanian, S., Jithesh, M. N., Rayorath, P., Hodges, D. M., et al. (2009). Seaweed extracts as biostimulants of plant growth and development. Journal of Plant Growth Regulation, 28(4), 386-399.

Kier, G., Kreft, H., Lee, T. M., Jetz, W., Ibisch, P. L., Nowicki, C., et al. (2009). A global assessment of endemism and species richness across island and mainland regions. Proceedings of the National Academy of Sciences, 106(23), 9323-9327.

Kinley, R. D., De Nys, R., Vucko, M. J., Machado, L., \& Tomkins, N. W. (2016). The red macroalgae Asparagopsis taxiformis is a potent natural antimethanogenic that reduces methane production during in vitro fermentation with rumen fluid. Animal Production Science, 56(3), 282-289.

Kuffner, I. B., Walters, L. J., Becerro, M. A., Paul, V. J., Ritson-Williams, R., \& Beach, K. S. (2006). Inhibition of coral recruitment by macroalgae and cyanobacteria. Marine Ecology Progress Series, 33, 107-117.

Kumari, P., Kumar, M., Gupta, V., Reddy, C. R. K., \& Jha, B. (2010). Tropical marine macroalgae as potential sources of nutritionally important PUFAs. Food Chemistry, 120, 749757.

Kumari, P., Singh, R. P., Bijo, A. J., Reddy, C. R. K., \& Jha, B. (2012). Estimation of lipid hydroperoxide levels in tropical marine macroalgae. Journal of Phycology, 48(6), 13621373 .

Kumar, G., \& Sahoo, D. (2011). Effect of seaweed liquid extract on growth and yield of Triticum aestivum var. Pusa Gold. Journal of Applied Phycology, 23(2), 251-255.

Kumar, P. S., \& Sudha, S. (2013). Biosynthesis of silver nanoparticles from Dictyota bartayresiana extract and their antifungal activity. Nano Biomedicine \& Engineering, 5, 72-75.

Lapointe, B. E. (1997). Nutrient thresholds for bottom-up control of macroalgal blooms on coral reefs in Jamaica and southeast Florida. Limnology and Oceanography, 42, 1119-1131.

Lapointe, B. E., Littler, M. M., \& Littler, D. S. (1997). Macroalgal overgrowth of fringing coral reefs at Discovery bay, Jamaica: Bottom-up versus top-down control. In Proceeding 8th international coral reefs symposium 1, Smithsonian Tropical Research Institute, Panama (pp. 927-932). 
Laurent, V., Maamaatuaiahutapu, K., Maiau, J., \& Varney, P. (2004). Atlas climatologique de la Polynésie française. Papeete: Meteo France.

Lewis, S. M., Norris, J. N., \& Searles, R. B. (1987). The regulation of morphological plasticity in tropical reef algae by herbivory. Ecology, 68(3), 636-641.

Littler, M. M., Littler, D. S., \& Brooks, B. L. (2006). Harmful algae on tropical coral reefs: Bottom-up eutrophication and top-down herbivory. Harmful Algae, 5(5), 565-585.

Lobban, C. S., \& Harrison, P. J. (1994). Seaweed ecology and physiology. New York: Press Syndicate Cambridge University.

Longo, G. O., \& Hay, M. E. (2015). Does seaweed-coral competition make seaweeds more palatable? Coral Reefs, 34, 87-96.

Longo, G. O., \& Hay, M. E. (2017). Seaweed allelopathy to corals: Are active compounds on, or in, seaweeds? Coral Reefs, 36, 247-253.

Lüning, K., \& Tom Dieck, I. (1989). Environmental triggers in algal seasonality. Botanica Marina, 32(5), 389-398.

Machado, L., Magnusson, M., Paul, N. A., De Nys, R., \& Tomkins, N. (2014). Effects of marine and freshwater macroalgae on in vitro total gas and methane production. PLoS One, 9(1). e85289, 1-11.

Mangaiyarkarasi, R., Kanna, L., Girija, M., \& Gnanamurthy, S. (2014). Screening of Indian marine macro algae (Seaweeds) for haemagglutinin activity. International Journal of Advanced Research, 2(4), 43-52.

Mantyka, C. S., \& Bellwood, D. R. (2007). Macroalgal grazing selectivity among herbivorous coral reef fishes. Marine Ecology Progress Series, 352, 177-185.

Mattio, L., Payri, C. E., \& Stiger-Pouvreau, V. (2008). Taxonomic revision of Sargassum (Fucales, Phaeophyceae) from French Polynesia based on morphological and molecular analyses. Journal of Phycology, 44, 1541-1555.

Maypa, A. P., \& Raymundo, L. J. (2004). Algae-coral interactions: Mediation of coral settlement, early survival and growth by macroalgae. Silliman Journal, 45, 76-95.

McCook, L. J., Jompa, J., \& Diaz-Pulido, G. (2001). Competition between corals and algae on coral reefs: A review of evidence and mechanisms. Coral Reefs, 19, 400-417.

Moore, J. W. (1974). Benthic algae of southern baffin island: II. The epipelic communities in temporary ponds. The Journal of Ecology, 809-819.

Mumby, P. J., Steneck, R. S., Adjeroud, M., \& Arnold, S. N. (2016). High resilience masks underlying sensitivity to algal phase shifts of Pacific coral reefs. Oikos, 125, 644-655.

N'Yeurt, A. D. R., \& Payri, C. E. (2009). Four new species of Rhodophyceae from Fiji, Polynesia and Vanuatu, South Pacific. Phycological Research, 57(1), 12-24.

Nelson, S. G., Glenn, E. P., Conn, J., Walsh, T., \& Akutagawa, M. (2001). Cultivation of Gracilaria parvispora (Rhodophyta) in shrimp-farm effluent ditches and floating cages in Hawaii: A two-phase polyculture system. Aquaculture, 193(3-4), 239-248.

Norris, J. N., \& Fenical, W. (1982). Chemical defenses in tropical marine algae. Atlantic barrier reef ecosystem, Carrie Bow Cay Belize. Smithsonian Contributions to the Marine Sciences, 12, 417-431.

Novaczek, I. (2001). A guide to the common edible and medicinal sea plants of the pacific islands, $3 A$. Community Fisheries Training Pacific Series, University of the South Pacific, Secretariat of the Pacific Community.

Nugues, M. M., Smith, G. W., Van Hooindonk, R. J., Seabra, M. I., \& Bak, R. P. M. (2004). Algal contact as a trigger for coral disease. Ecology Letters, 7, 919-923.

N'Yeurt, A. D. R., \& Iese, V. (2015a). The proliferating brown alga Sargassum polycystum in Tuvalu, South Pacific: Assessment of the bloom and applications to local agriculture and sustainable energy. Journal of Applied Phycology, 27(5), 2037-2045.

N'Yeurt, A. D. R., \& Iese, V. (2015b). Erratum to: The proliferating brown alga Sargassum polycystum in Tuvalu, South Pacific: Assessment of the bloom and applications to local agriculture and sustainable energy. Journal of Applied Phycology, 5(27), 2047. 
N'Yeurt, A. D. R., \& Payri, C. E. (2006). Marine algal flora of French Polynesia I. Phaeophyceae (Ochrophyta, brown algae). Cryptogamie Algologie, 27(2), 111-152.

N'Yeurt, A. D. R., \& Payri, C. E. (2007). Marine algal Flora of French Polynesia II. Chlorophyceae (green algae). Cryptogamie Algologie, 28(1), 3-88.

N'Yeurt, A. D. R., \& Payri, C. E. (2010). Marine algal flora of French Polynesia III. Rhodophyta, with additions to the Phaeophyceae and Chlorophyta. Cryptogamie Bryologie, 31(1), 3-205.

Palanisamy, S., Sellappa, S., \& Stella, C. (2010). Antioxidant properties of methanolic extract of Dictyota batresiana from south east coast of India. Journal of Pharmacy Research, 3(12), 2974-2976.

Pandithurai, M., \& Murugesan, S. (2014). Free radical scavenging activity of methanolic extract of brown alga Spatoglossum asperum. Journal of Chemical and Pharmaceutical Research, 6, 128-132.

Pandithurai, M., Murugesan, S., \& Sivamurugan, V. (2015). Antibacterial activity of various solvent extracts of marine brown alga Spatoglossum asperum. International Journal of Pharmacology Research, 5(6), 133-138.

Pardo-Vargas, A., de Oliveira, I. B., Stephens, P. R. S., Cirne-Santos, C. C., Palmer Paixão, I. C. N., Ramos, F. A., et al. (2014). Dolabelladienols A-C, new diterpenes isolated from Brazilian Brown alga Dictyota pfaffii. Marine Drugs, 12, 4247-4259.

Parmar, P. V., Solanki, J. B., Nanjiyani, R. P., Kamaliya, N. L., Chavda, V. M., Parmar, H. V., et al. (2016). Antibacterial activity of seaweeds from Veraval coast. The Bioscan, 11(4), 2133-2135.

Patil, A. D., Berry, D., Brooks, D. P., Hemling, M. E., Kumar, N. V., Mitchell, M. P., et al. (1993). A diterpene epoxide from the marine brown alga Dictyota sp.: Possible vasopressin V1 receptor antagonist. Phytochemistry, 33(5), 1061-1064.

Paul, V. J., Kuffner, I. B., Walters, L. J., Ritson-Williams, R., Beach, K. S., \& Becerro, M. A. (2011). Chemically mediated interactions between macroalgae Dictyota spp. and multiple life-history stages of the coral Porites astreoides. Marine Ecology Progress Series, 426, 161170 .

Paul, V. J., \& Puglisi, M. P. (2004). Chemical mediation of interactions among marine organisms. Natural Product Report, 21, 189-209.

Payri, C. E. (1982). Les Macrophytes du Lagon de Tiahura (Île de Moorea, Polynésie française). Thèse de troisième cycle. Montpellier: Université des Sciences et des Techniques du Languedoc.

Payri, C. E., \& Denizot, M. (1993). Les Peuplements d'Algues. In ORSTOM (Ed.), Atlas de la Polynésie française. pl. 49. Paris.

Payri, C. E., \& Meinesz, A. (1985). Algae. In B. Delesalle, R. Galzin, \& B. Salvat (Eds.), French polynesian coral reefs: Vol. 1. Proceedings of the 5 th international coral reef congress, Tahiti, 27 May-1 June 1985 (pp. 498-518).

Payri, C. E., \& N'Yeurt, A. D. R. (1997). A revised checklist of Polynesian benthic marine. Algae. Australian Systematic Botany, 10, 867-910.

Payri, C. E., N’Yeurt, A. D. R., Fiat, S., \& Andréfouët, S. (2016). Macroflore marine des Marquises. Biodiversité Marine et Terrestre des Marquises, 207-219.

Payri, C. E., \& Stiger, V. (2001). Macroalgal community changes on French Polynesian reefs, 1980-2000. Phycologia, 40(4), 111.

Pereira, R. C., Cavalcanti, D. N., \& Teixeira, V. L. (2000). Effects of secondary metabolites from the tropical Brazilian brown alga Dictyota menstrualis on the amphipod Parhyale hawaiensis. Marine Ecology Progress Series, 205, 95-100.

Pheulpin, L., Recking, A., Sichoix, L., \& Barriot, J.-P. (2016). Extreme floods regionalisation in the tropical island of Tahiti, French Polynesia. In European Conference on Flood Risk Management, E3S Web of Conferences, 7, 01014. 
Pheulpin, L., Sichoix, L., Barriot, J.-P., \& Recking, A. (2014). An example of flash-flood events in Tahiti, French Polynesia. In International conference on Earth observations and societal impacts.

Philippus, A. C., Zatelli, G. A., Wanke, T., Barros, M. G. A., Kami, S. A., Lhullier, C., et al. (2018). Molecular networking prospection and characterization of terpenoids and $\mathrm{C}_{15^{-}}$ acetogenins in Brazilian seaweed extracts. Royal Society of Chemistry, 8, 29654-29661.

Rajamani, K., Balasubramanian, T., \& Thirugnanasambandan, S. S. (2018). Bioassay-guided isolation of triterpene from brown alga Padina boergesenii possess anti-inflammatory and anti-angiogenic potential with kinetic inhibition of $\beta$-carotene linoleate system. $L W T$ Food Science and Technology, 93, 549-555.

Rasher, D. B., \& Hay, M. E. (2010). Chemically rich seaweeds poison corals when not controlled by herbivores. Proceedings of the National Academy of Sciences, 107(21), 96839688.

Rasher, D. B., \& Hay, M. E. (2014). Competition induces allelopathy but suppresses growth and anti-herbivore defence in a chemically rich seaweed. Proceedings of the Royal Society B, 281, 20132615, 1-9.

Rasher, D. B., Hoey, A. S., \& Hay, M. E. (2013). Consumer diversity interacts with prey defences to drive ecosystem function. Ecology, 94(6), 1347-1358.

Rasher, D. B., Stout, E. P., Engel, S., Kubanek, J., \& Hay, M. E. (2011). Chemically rich seaweeds poison corals when not controlled by herbivores. Proceedings of the National Academy of Sciences, 108(43), 17726-17731.

Renaud, P. E., Hay, M. E., \& Schmitt, T. M. (1990). Interactions of plant stress and herbivory: Intraspecific variation in the susceptibility of a palatable versus an unpalatable seaweed to sea urchin grazing. Oecologia, 82(2), 217-226.

Reverter, M., Bontemps, N., Lecchini, D., Banaigs, B., \& Sasal, P. (2014). Use of plant extracts in fish aquaculture as an alternative to chemotherapy: Current status and future perspectives. Aquaculture, 433, 50-61.

Reverter, M., Saulnier, D., David, R., Bardon-Albaret, A., Belliard, C., TapissierBontemps, N., et al. (2016). Effects of local Polynesian plants and algae on growth and expression of two immune-related genes in orbicular batfish (Platax orbicularis). Fish and Shellish Immunology, 58, 82-88.

Rita-Williams, R., Arnold, S. N., Fogarty, N. D., Steneck, R. S., Vermeij, M. J., \& Paul, V. J. (2009). New perspectives on ecological mechanisms affecting coral recruitment on reefs. Smithsonian Contributions to the Marine Sciences, 38, 437-457.

Rohfritsch, A., Payri, C., Stiger, V., \& Bonhomme, F. (2007). Molecular and morphological relationships between two closely related species, Turbinaria ornata and T. conoides (Sargassaceae, Phaeophyceae). Biochemical Systematics and Ecology, 35, 91-98.

Rohfritsch, A., Payri, C., Stiger, V., \& Bonhomme, F. (2010). Habitat-related allelic variation revealed by an anonymous DNA locus in reef-dwelling Turbinaria ornata (Fucales, Phaeophyceae). Botanica Marina, 53, 189-192.

Salvador, N., Gómez Garreta, A., Lavelli, L., \& Ribera, M. A. (2007). Antimicrobial activity of Iberian macroalgae. Scientia Marina, 71(1), 101-113.

Sameeh, M. Y., Mohamed, A. A., \& Elazzazy, A. M. (2016). Polyphenolic contents and antimicrobial activity of different extracts of Padina boryana Thivy and Enteromorpha sp marine algae. Journal of Applied Pharmaceutical Science, 6(9), 87-92.

Sanciangco, J. C., Carpenter, K. E., Etnoyer, P. J., \& Moretzsohn, F. (2013). Habitat availability and Heterogeneity and the Indo-pacific warm pool as predictors of marine species richness in the tropical Indo-pacific. PLoS One, 8(2). e56245, 1-18.

Sangil, C., Sansón, M., Clemente, S., Afonso-Carrillo, J., \& Hernández, J. C. (2014). Contrasting the species abundance, species density and diversity of seaweed assemblages in alternative states: Urchin density as a driver of biotic homogenization. Journal of Sea Research, 85, 92-103. 
Sarma, N. S., Krishna, M. S. R., \& Pasha, S. G. (2006). Marine algal natural products: Contributions from India in the global context. Indian Journal of Chemistry, Section B, 45B, 433-449.

Sasaki, H., Kataoka, H., Kamiya, M., \& Kawai, H. (1999). Accumulation of sulfuric acid in Dictyotales (Phaeophyceae): Taxonomic distribution and ion chromatography of cell extracts. Journal of Phycology, 35, 732-739.

Sasaki, H., Kataoka, H., Murakami, A., \& Kawai, H. (2004). Inorganic ion compositions in brown algae, with special reference to sulfuric acid ion accumulations. Hydrobiologia, 512, 255-262.

Schmitt, T. M., Hay, M. E., \& Lindquist, N. (1995). Constraints on chemically mediated coevolution: Multiple functions for seaweed secondary metabolites. Ecology, 76, 107123.

Schupp, P. J., \& Paul, V. J. (1994). Calcium carbonate and secondary metabolites in tropical seaweeds: Variable effects on herbivorous fishes. Ecology, 75(4), 1172-1185.

Setchell, W. A. (1926). Tahitian Algae collected by W. A. Setchell, C. B. Setchell and H. E. Parks (Vol. 12, pp. 61-142). University of California Publications in Botany.

Sharifian, S., Shahbanpour, B., Taheri, A., \& Kordjazi, M. (2019). Effect of phlorotannins on melanosis and quality changes of Pacific white shrimp (Litopenaeus vannamei) during iced storage. Food Chemistry, 298, 124980.

Shevchenko, N. M., Usol'tseva, R. V., Ishina, I. A., Thinh, P. D., Ly, B. M., \& Ermakova, S. P. (2017). Structural characteristics and in vitro antitumor activity of water-soluble polysaccharides from brown algae of the Russian Far East and Vietnam. Chemistry of Natural Compounds, 53(1), 1-5.

Siddhanta, A. K., Prasad, K., Meena, R., Prasad, G., Mehta, G. K., Chhatbar, M. U., et al. (2009). Profiling of cellulose content in Indian seaweed species. Bioresource Technology, 100, 6669-6673.

Silberfeld, T., Rousseau, F., \& De Reviers, B. (2014). An updated classification of brown algae (Ochrophyta, Phaeophyceae). Cryptogamie Algologie, 35(2), 117-157.

Sivakumar, S. R., \& Vignesh, A. (2014). In vitro activity of seaweed extracts collected from Gulf of Mannar coast islands, Tamilnadu on clinical isolates. International Journal of Pharmaceutical and Biological Archives, 5(3), 99-103.

Smith, J. E., Hunter, C. L., \& Smith, C. M. (2010). The effects of top-down versus bottomup control on benthic coral reef community structure. Oecologia, 163(2), 497-507.

Soares, D. C., Calegari-Silva, T. C., Lopes, U. G., Teixeira, V. L., De Palmer Paixão, I. C. N., Cirne-Santos, C., et al. (2012). Dolabelladienetriol, a compound from Dictyota pfaffii algae, inhibits the infection by Leishmania amazonensis. PLoS One, Neglected Tropical Diseases, 6(9), e1787, 1-12.

Sotka, E. E., Bell, T., Hughes, L. E., Lowry, J. K., \& Poore, A. G. (2017). A molecular phylogeny of marine amphipods in the herbivorous family Ampithoidae. Zoologica Scripta, 46(1), 85-95.

Sotka, E. E., \& Hay, M. E. (2009). Effects of herbivores, nutrient enrichment, and their interactions on macroalgal proliferation and coral growth. Coral Reefs, 28, 555-568.

South, G. R. (1993). Edible seaweeds of Fiji: An ethnobotanical study. Botanica Marina, 36, $335-349$.

Steinberg, P. D., \& De Nys, R. (2002). Chemical mediation of colonization of seaweed surfaces. Journal of Phycology, 38, 621-629.

Steinberg, P. D., \& Paul, V. J. (1990). Fish feeding and chemical defences of tropical brown algae in Western Australia. Marine Ecology Progress Series, 58, 253-259.

Stephens, P. R. S., Cirne-Santos, C. C., De Souza Barros, C., Teixeira, V. L., Carneiro, L. A. D., Dos Santos De Amorim, L., et al. (2017). Diterpene from marine brown alga Dictyota friabilis as a potential microbicide against HIV-1 in tissue explants. Journal of Applied Phycology, 29(2), 775-780. 
Stiger, V., \& Payri, C. E. (1999a). Spatial and temporal patterns of settlement of the brown macroalgae Turbinaria ornata and Sargassum mangarevense in a coral reef on Tahiti. Marine Ecology Progress Series, 191, 91-100.

Stiger, V., \& Payri, C. E. (1999b). Spatial and seasonal variations in the biological characteristics of two invasive brown algae, Turbinaria ornata (Turner) J. Agardh and Sargassum mangarevense (grunow) setchelll (Sargassaceae, Fucales) spreading on the reefs of Tahiti (French Polynesia). Botanica Marina, 42, 295-306.

Teixeira, V. L., \& Kelecom, A. (1988). A chemotaxonomic study of diterpenes from marine brown algae of the genus Dictyota. The Science of the Total Environment, 75, 271-283.

Trapon, M. L., Pratchett, M. S., \& Penin, L. (2011). Comparative effects of different disturbances in coral reef habitats in Moorea, French Polynesia. Journal of Marine Biology, $807625,1-11$.

Tronholm, A., Sansón, M., Afonso-Carrillo, J., Verbruggen, H., \& De Clerck, O. (2010). Niche partitioning and the coexistence of two cryptic Dictyota (Dictyotales, Phaeophyceae) species from the canary islands. Journal of Phycology, 46(6), 1075-1087.

Tronholm, A., Steen, F., Tyberghein, L., Leliaert, F., Verbruggen, H., Antonia Ribera Siguan, M., et al. (2010). Species delimitation, taxonomy, and biogeography of Dictyota in Europe (Dictyotales, Phaeophyceae). Journal of Phycology, 46(6), 1301-1321.

Usoltseva, R. V., Anastyuk, S. D., Ishina, I. A., Isakov, V. V., Zvyagintseva, T. N., Thinh, P. D., et al. (2018). Structural characteristics and anticancer activity in vitro of fucoidan from brown alga Padina boryana. Carbohydrate Polymers, 184, 260-268.

Vallim, M. A., De Paula, J. C., Pereira, R. C., \& Teixeira, V. L. (2005). The diterpenes from Dictyotacean marine brown algae in the Tropical Atlantic American region. Biochemical Systematics and Ecology, 33, 1-16.

Van Hees, D. H., Olsen, Y. S., Wernberg, T., Van Alstyne, K. L., \& Kendrick, G. A. (2017). Phenolic concentrations of brown seaweeds and relationships to nearshore environmental gradients in Western Australia. Marine Biology, 164, 74.

Van Steveninck, E. D. R., \& Breeman, A. M. (1987). Population dynamics of a tropical intertidal and deep-water population of Sargassum polyceratium (Phaeophyceae). Aquatic Botany, 29(2), 139-156.

Verbruggen, H., De Clerck, O., N’Yeurt, A. D., Spalding, H., \& Vroom, P. S. (2006). Phylogeny and taxonomy of Halimeda incrassata, including descriptions of H. kanaloana and H. heteromorpha spp. nov.(Bryopsidales, Chlorophyta). European Journal of Phycology, 41(3), 337-362.

Vieira, C., Camacho, O., Sun, Z., Fredericq, S., Leliaert, F., Payri, C., et al. (2017). Historical biogeography of the highly diverse brown seaweed Lobophora (Dictyotales, Phaeophyceae). Molecular Phylogenetics and Evolution, 110, 81-92.

Vieira, C., Camacho, O., Wynne, M. J., Mattio, L., Anderson, R. J., Bolton, J. J., et al. (2016). Shedding new light on old algae: Matching names and sequences in brown algal genus Lobophora (Dictyotales, Phaeophyceae). Taxon, 65(4), 689-707.

Vieira, C., Engelen, A. H., Guentas, L., Aires, T., Houlbreque, F., Gaubert, J., et al. (2016). Species specificity of bacteria associated to the brown seaweeds Lobophora (Dictyotales, Phaeophyceae) and their potential for induction of rapid coral bleaching in Acropora muricata. Frontiers in Microbiology, 7(316), 1-13.

Vieira, C., Payri, C., \& De Clerck, O. (2015). Overgrowth and killing of corals by the brown alga Lobophora hederacea (Dictyotales, Phaeophyceae) on healthy reefs in New Caledonia: A new case of the epizoism syndrome. Phycological Research, 63, 152-153.

Vieira, C., Stenger, P. L., Moleana, T., De Clerck, O., \& Payri, C. (2019). Limited interspecific variation in grazing susceptibility of the brown alga Lobophora to herbivory. Journal of Experimental Marine Biology and Ecology, 518, 151175. 
Vinayak, R. C., Sabu, A. S., \& Chatterji, A. (2011). Bio-prospecting of a few brown seaweeds for their cytotoxic and antioxidant activities. Evidence-based Complementary and Alternative Medicine, 673083, 1-9.

Walters, R. G., Ruban, A. V., \& Horton, P. (1996). Identification of proton-active residues in a higher plant light-harvesting complex. Proceedings of the National Academy of Sciences of the United States of America, 93, 14204-14209.

Zatelli, G. A., Philippus, A. C., \& Falkenberg, M. (2018). An overview of odoriferous marine seaweeds of the Dictyopteris genus: Insights into their chemical diversity, biological potential and ecological roles. Revista Brasileira de Farmacognosia, 28(2), 243-260.

Zizka, M. D. (2012). Sea Urchins on the move: Distribution change of Echinometra in Mo'orea French Polynesia. Berkeley Scientific Journal, 15(1).

Zubia, M., Andréfouët, S., \& Payri, C. (2014). Distribution and biomass evaluation of drifting brown algae from Moorea lagoon (French Polynesia) for eco-friendly agricultural use. Journal of Applied Phycology, 27, 1277-1287.

Zubia, M., Depetris, M., Flores, O., Turquet, J., \& Cuet, P. (2018). Macroalgae as a tool for assessing the ecological status of coral reefs under the water framework directive: A case study on the reef flats of La Réunion (Indian Ocean). Marine Pollution Bulletin, 137, 339351.

Zubia, M., \& Mattio, L. (2019). Macroalgues tropicales; une ressource durable d'avenir. Techniques de l'ingénieur BIO 9040.

Zubia, M., Payri, C., \& Deslandes, E. (2008). Alginate, mannitol, phenolic compounds and biological activities of two range-extending brown algae, Sargassum mangarevense and Turbinaria ornata (Phaeophyta: Fucales), from Tahiti (French Polynesia). Journal of Applied Phycology, 20, 1033-1043.

Zubia, M., Payri, C. E., Deslandes, E., \& Guezennec, J. (2003). Chemical composition of attached and drift specimens of Sargassum mangarevense and Turbinaria ornata (Phaeophyta: Fucales) from Tahiti, French Polynesia. Botanica Marina, 46(6), 562-571. 